Review

\title{
Progress in research on catalysts for catalytic oxidation of formaldehyde
}

\author{
Bingyang Bai a,b,\#, Qi Qiao ${ }^{\text {a,b }}$, Junhua Li c,*, Jiming Hao ${ }^{c}$ \\ a State Key Laboratory of Environmental Criteria and Risk Assessment, Chinese Research Academy of Environmental Sciences, Beijing 100012, China \\ ${ }^{\mathrm{b}}$ Key Laboratory of Eco-Industry of the Ministry of Environmental Protection, Chinese Research Academy of Environmental Sciences, Beijing 100012, \\ China \\ c State Key Joint Laboratory of Environment Simulation and Pollution Control, School of Environment, Tsinghua University, Beijing 100084, China
}

\section{A R T I C L E I N F 0}

\section{Article history:}

Received 27 August 2015

Accepted 20 October 2015

Published 5 January 2016

\section{Keywords:}

Formaldehyde

Catalytic oxidation

Metal oxide catalyst

Noble metal catalyst

Low-temperature catalytic activity

\begin{abstract}
A B S T R A C T
Formaldehyde (HCHO) is carcinogenic and teratogenic, and is therefore a serious danger to human health. It also adversely affects air quality. Catalytic oxidation is an efficient technique for removing $\mathrm{HCHO}$. The development of highly efficient and stable catalysts that can completely convert $\mathrm{HCHO}$ at low temperatures, even room temperature, is important. Supported Pt and Pd catalysts can completely convert $\mathrm{HCHO}$ at room temperature, but their industrial applications are limited because they are expensive. The catalytic activities in $\mathrm{HCHO}$ oxidation of transition-metal oxide catalysts such as manganese and cobalt oxides with unusual morphologies are better than those of traditional $\mathrm{MnO}_{2}, \mathrm{Co}_{3} \mathrm{O}_{4}$, or other metal oxides. This is attributed to their specific structures, high specific surface areas, and other factors such as active phase, reducibility, and amount of surface active oxygens. Such catalysts with various morphologies have great potential and can also be used as catalyst supports. The loading of relatively cheap Ag or Au on transition-metal oxides with special morphologies potentially improves the catalytic activity in $\mathrm{HCHO}$ removal at room temperature. The preparation and development of new nanocatalysts with various morphologies and structures is important for HCHO removal. In this paper, research progress on precious-metal and transition-metal oxide catalyst systems for $\mathrm{HCHO}$ oxidation is reviewed; topics such as oxidation properties, structure-activity relationships, and factors influencing the catalytic activity and reaction mechanism are discussed. Future prospects and directions for the development of such catalysts are also covered.
\end{abstract}

(C) 2016, Dalian Institute of Chemical Physics, Chinese Academy of Sciences. Published by Elsevier B.V. All rights reserved.

\section{Introduction}

Formaldehyde (HCHO) is a colorless gas with a strong irritating smell at atmospheric pressure. Outdoor HCHO mainly comes from the production of materials such as paints, textiles, printing materials, pesticides, and adhesives, and from motor vehicle exhausts. Indoor HCHO mainly comes from decorating materials, plywood, fiberboard, particleboard, and other artificial boards [1]. HCHO has serious adverse effects on human health and causes conditions such as edema, eye irritation, headaches, allergic dermatitis, and dark sports. Inhalation of $\mathrm{HCHO}$ at high concentrations can induce bronchial asthma, and HCHO can combine with protein amino groups to cause cell mutation. The damage caused by HCHO to human health is

\footnotetext{
* Corresponding author. Tel/Fax: +86-10-62771093; E-mail: lijunhua@tsinghua.edu.cn

\# Corresponding author. Tel: +86-10-84914902; Fax: +86-10-84914626; E-mail: baibingyang@tsinghua.org.cn

This work was supported by the National Natural Science Foundation of China $(21325731,51478241,21221004)$.

DOI: 10.1016/S1872-2067(15)61007-5 | http://www.sciencedirect.com/science/journal/18722067 | Chin. J. Catal., Vol. 37, No. 1, January 2016
} 
closely related to its concentration in air and contact time. It has been classified as carcinogenic and teratogenic by the World Health Organization [2,3]. HCHO is also a volatile organic compound (VOC) and has strong photochemical activity, e.g., it can react photochemically with nitrogen oxides $\left(\mathrm{NO}_{x}\right)$ [4-7]. $\mathrm{HCHO}$ removal is therefore necessary to protect human health and the atmospheric environment.

The main techniques used in the elimination of VOCs are adsorption, and photocatalytic and catalytic oxidation methods [8-21]. Adsorption usually uses activated carbon or molecular sieves as adsorbents for HCHO removal [22-33]. The use of this method is restricted because of the limitations of adsorption capacity and adsorbent regeneration. Photocatalytic methods often use $\mathrm{TiO}_{2}$-based catalysts to remove $\mathrm{HCHO}$ [34-41]. In actual applications, wall paints containing modified $\mathrm{TiO}_{2}$ catalysts are used. However, under light, such paints can produce secondary pollution of toxicity similar to that of HCHO. Catalytic oxidation is a promising technique, and has advantages such as high removal efficiency, low light-off temperature, wide application scope, simple equipment, and no secondary pollution. $\mathrm{HCHO}$ can be directly converted to $\mathrm{CO}_{2}$ and $\mathrm{H}_{2} \mathrm{O}$ [42].

The development of catalytic oxidation techniques is important. The catalytic materials for HCHO oxidation are mainly divided into noble-metal and transition-metal oxide catalyst systems. In this paper, we review progress in research on these two systems in detail, and future directions and potential hotspots in research on catalysts for HCHO oxidation are discussed.

\section{Noble-metal catalysts}

Noble-metal catalyst attract much attention because of their excellent low-temperature oxidation activities. They are loaded on supports because precious metals themselves are easily volatilized, oxidized, and sintered. The loading of precious metals on supports enables HCHO conversion at low temperatures. The specific catalytic properties are related to factors such as precious-metal and support types, and structure. The precious-metal catalysts currently used for HCHO oxidation mainly contain Pt, Pd, Au, and Ag as the active components [43]. Other precious metals are not suitable for catalytic combustion because of their high volatilities and ease of oxidation at high temperatures. The supports for precious-metal catalysts for HCHO oxidation can be divided into three types. The first type is materials with no oxidation activities and large specific surface areas, such as $\mathrm{SiO}_{2}, \mathrm{Al}_{2} \mathrm{O}_{3}, \mathrm{TiO}_{2}$, and molecular sieves; these are common catalyst supports and are commercially available. The second type is single or mixed metal oxides without special morphologies, with high-temperature oxidation activities, but low specific surface areas; examples are bulk $\mathrm{CeO}_{2}$ and $\mathrm{MnO}_{2}$; these are traditional metal oxide supports. The third type is metal oxides with special morphologies such as nanorods and

Table 1

Overview of catalytic activities in HCHO oxidation of supported noble-metal catalysts.

\begin{tabular}{|c|c|c|c|}
\hline Catalysts & Reaction conditions & $T_{50}\left({ }^{\circ} \mathrm{C}\right)$ & Ref. \\
\hline \multicolumn{4}{|c|}{ Common supports } \\
\hline $\mathrm{Pt} / \mathrm{TiO}_{2}$ & $100 \mathrm{ppm}$ HCHO, 20 vol\% $\mathrm{O}_{2}, 50000 \mathrm{~h}^{-1} \mathrm{SV}$ & R.T. & {$[44,45]$} \\
\hline $\mathrm{Rh} / \mathrm{TiO}_{2}$ & & 50 & \\
\hline $\mathrm{Pd} / \mathrm{TiO}_{2}$ & & 70 & \\
\hline $\mathrm{Au} / \mathrm{TiO}_{2}$ & & 90 & \\
\hline $\mathrm{Na}-\mathrm{Pt} / \mathrm{TiO}_{2}$ & $600 \mathrm{ppm}$ HCHO, 20 vol\% $\mathrm{O}_{2}, 300000 \mathrm{~h}^{-1} \mathrm{SV}, 50 \%$ relative humidity & R.T. & [46] \\
\hline $\mathrm{Na}-\mathrm{Pt} / \mathrm{TiO}_{2}$ & 105 ppm $\mathrm{HCHO}$ and 315 ppm toluene & R.T. & {$[47]$} \\
\hline $\mathrm{Pt} / \mathrm{TiO}_{2}(\mathrm{C})$ & $36 \mathrm{ppm} \mathrm{HCHO}, 21 \mathrm{vol} \% \mathrm{O}_{2}$, total flow $500 \mathrm{~mL} / \mathrm{min}$ & R.T. & {$[48]$} \\
\hline $\mathrm{Pt} / \mathrm{f}-\mathrm{SiO}_{2}$ & $300 \mathrm{ppm}$ HCHO, $20 \mathrm{vol} \% \mathrm{O}_{2}, 30000 \mathrm{~mL} /(\mathrm{g} \cdot \mathrm{h}) \mathrm{SV}$ & R.T. & [49] \\
\hline Pt/SBA-15 & & 40 & \\
\hline $\mathrm{Pt} / \mathrm{p}-\mathrm{SiO}_{2}$ & & 90 & \\
\hline $\mathrm{Pt} / \mathrm{TiO}_{2}$ & 100 ppm HCHO, 22 vol\% O, $300000 \mathrm{~mL} /(\mathrm{g} \cdot \mathrm{h}) \mathrm{SV}$ & R.T. & {$[50]$} \\
\hline $\mathrm{Pd} / \mathrm{TiO}_{2}$ & & 80 & \\
\hline $\mathrm{Rh} / \mathrm{TiO}_{2}$ & & 90 & \\
\hline $\mathrm{Pt} / \mathrm{SiO}_{2}$ & & 60 & \\
\hline Pt/carbon & $100-300$ ppm HCHO, 22 vol\% $\mathrm{O}_{2}, 1120 \mathrm{~h}^{-1} \mathrm{SV}$ & $<100$ & [51] \\
\hline $\mathrm{Pt} / \mathrm{TiO}_{2}$ & $10 \mathrm{ppm} \mathrm{HCHO}, 80000 \mathrm{~h}^{-1} \mathrm{SV}, 50 \%$ relative humidity & R.T. & {$[52]$} \\
\hline $\mathrm{Pd} / \mathrm{TiO}_{2}$ & $10 \mathrm{ppm}$ HCHO, $120000 \mathrm{~h}^{-1} \mathrm{SV}, 50 \%$ relative humidity & R.T. & [53] \\
\hline Pd/Bata & 40 ppm HCHO, 20 vol\% $\% \mathrm{O}_{2}, 50000 \mathrm{~h}^{-1} \mathrm{SV}, 3 \% \mathrm{H}_{2} \mathrm{O}$ & $<40$ & {$[54]$} \\
\hline Pd/USY & & $<40$ & \\
\hline $\mathrm{Pd} / \mathrm{ZSM}-5$ & & 70 & \\
\hline Pd/HM10 & & $>140$ & \\
\hline $\mathrm{Pd} / \mathrm{Zeo}-13 \mathrm{X}$ & & $<40$ & \\
\hline $\mathrm{Pd} / \mathrm{Al}_{2} \mathrm{O}_{3}$ & & $<40$ & \\
\hline $\mathrm{PdMn} / \mathrm{Al}_{2} \mathrm{O}_{3}$ & $0.5 \% \mathrm{HCHO}, 0.2 \% \mathrm{CH}_{3} \mathrm{OH}, 0.7 \% \mathrm{H}_{2} \mathrm{O}, 75.6 \% \mathrm{~N}_{2}, 23 \% \mathrm{O}_{2}$ & 60 & [55] \\
\hline $\mathrm{Ag} / \mathrm{SBA}-15$ & 1000 ppm HCHO, 15 vol\% $\mathrm{O}_{2}, 15000 \mathrm{~mL} /(\mathrm{g} \cdot \mathrm{h}) \mathrm{SV}$ & 50 & [56] \\
\hline $\mathrm{Ag} / \mathrm{Al}_{2} \mathrm{O}_{3}$ & $1.2 \% \mathrm{HCHO}, 14.8 \% \mathrm{O}_{2}, 1000$ or $7000 \mathrm{~h}^{-1} \mathrm{SV}$ & - & [57] \\
\hline \multicolumn{4}{|l|}{$\mathrm{Ag} / \mathrm{SiO}_{2}$} \\
\hline $\mathrm{Ru} / \mathrm{Al}_{2} \mathrm{O}_{3}$ & 900 ppm HCHO, $160 \mathrm{ppm} \mathrm{CH}_{3} \mathrm{OH}, 18 \% \mathrm{H}_{2} \mathrm{O}, 82 \%$ air, $20000 \mathrm{~h}^{-1} \mathrm{SV}$ & 198 & {$[58]$} \\
\hline $\mathrm{Ru} /$ zeolite & & 210 & \\
\hline $\mathrm{Ru} / \mathrm{TiO}_{2}$ & & 212 & \\
\hline
\end{tabular}


Table 1 (Continued)

\begin{tabular}{|c|c|c|c|}
\hline Catalysts & Reaction conditions & $T_{50}\left({ }^{\circ} \mathrm{C}\right)$ & Ref. \\
\hline \multicolumn{4}{|c|}{ Traditional metal oxide supports } \\
\hline $\mathrm{Pt} / \mathrm{CeO}_{2}$ & 900 ppm HCHO, 160 ppm CH $30 \mathrm{OH}, 18 \% \mathrm{H}_{2} \mathrm{O}, 82 \%$ air, $20000 \mathrm{~h}^{-1} \mathrm{SV}$ & $<150$ & [58] \\
\hline $\mathrm{Pd} / \mathrm{CeO}_{2}$ & & $<150$ & \\
\hline $\mathrm{Rh} / \mathrm{CeO}_{2}$ & & $<150$ & \\
\hline $\mathrm{Ru} / \mathrm{CeO}_{2}$ & & $<150$ & \\
\hline $\mathrm{Rh} / \mathrm{ZrO}_{2}$ & & 188 & \\
\hline $\mathrm{Ir} / \mathrm{CeO}_{2}$ & & 207 & \\
\hline $\mathrm{Ag} / \mathrm{CeO}_{2}$ & $0.42 \% \mathrm{HCHO}, 0.074 \% \mathrm{CH}_{3} \mathrm{OH}, 19.9 \% \mathrm{H}_{2} \mathrm{O}, 62.7 \% \mathrm{~N}_{2}, 16.9 \% \mathrm{O}_{2}, 21000 \mathrm{~h}^{-1} \mathrm{SV}$ & $<150$ & [61] \\
\hline $\mathrm{Pt} / \mathrm{MnO}_{x}-\mathrm{CeO}_{2}$ & $580 \mathrm{ppm}$ HCHO, 20 vol\% $\mathrm{O}_{2}, 30000 \mathrm{~mL} /(\mathrm{g} \cdot \mathrm{h}) \mathrm{SV}$ & R.T. & [62] \\
\hline $\mathrm{Ag} / \mathrm{MnO}_{x}-\mathrm{CeO}_{2}$ & $580 \mathrm{ppm}$ HCHO, 18 vol $\% \mathrm{O}_{2}, 30000 \mathrm{~mL} /(\mathrm{g} \cdot \mathrm{h}) \mathrm{SV}$ & 70 & [63] \\
\hline $\mathrm{Ag} / \mathrm{CeO}_{2}$ & & 90 & \\
\hline $\mathrm{Ag} / \mathrm{MnO}_{x}$ & & 115 & \\
\hline $\mathrm{Pt} / \mathrm{CeZrO}_{2}$ & $100 \mathrm{ppm} \mathrm{HCHO,} 22$ vol\% O, $300000 \mathrm{~mL} /(\mathrm{g} \cdot \mathrm{h}) \mathrm{SV}$ & $>120$ & {$[50]$} \\
\hline $\mathrm{Pd} / \mathrm{Mn}-\mathrm{CeO}_{2}$ & $40 \mathrm{ppm} \mathrm{HCHO}, 50000 \mathrm{~mL} /(\mathrm{g} \cdot \mathrm{h}) \mathrm{SV}, 3 \% \mathrm{H}_{2} \mathrm{O}$ & 110 & {$[54]$} \\
\hline $\mathrm{Au} / \mathrm{CeO}_{2}$ & $0.06 \% \mathrm{HCHO}, 32000 \mathrm{~mL} /(\mathrm{g} \cdot \mathrm{h}) \mathrm{SV}$ & 90 & {$[64]$} \\
\hline $\mathrm{Au} / \mathrm{CeO}_{2}$ & $500 \mathrm{ppm}$ HCHO, 20 vol\% $\mathrm{O}_{2}, 35400 \mathrm{~h}^{-1} \mathrm{SV}$ & $<40$ & [65] \\
\hline $\mathrm{Au} / \mathrm{Fe}-\mathrm{O}$ & $6.25 \mathrm{mg} / \mathrm{m}^{3} \mathrm{HCHO}, 54000 \mathrm{~mL} /(\mathrm{g} \cdot \mathrm{h}) \mathrm{SV}$ & 40 & [66] \\
\hline $\mathrm{Pt} / \mathrm{Fe}_{2} \mathrm{O}_{3}$ & 100-500 ppm HCHO, $60000 \mathrm{~mL} /(\mathrm{g} \cdot \mathrm{h}) \mathrm{SV}$ & R.T. & [67] \\
\hline $\mathrm{Pt} / \mathrm{K}-\mathrm{OMS}$ & 460 ppm HCHO, 21 vol\% $\mathrm{O}_{2}, 30000 \mathrm{~mL} /(\mathrm{g} \cdot \mathrm{h}) \mathrm{SV}$ & $>200$ & {$[68]$} \\
\hline $\mathrm{Ag} / \mathrm{K}-\mathrm{OMS}$ & & $>200$ & \\
\hline \multicolumn{4}{|c|}{ Metal oxide supports with special morphologies } \\
\hline $\mathrm{Pt} /$ nest-like $\mathrm{MnO}_{2}$ & $460 \mathrm{ppm} \mathrm{HCHO,} 20000 \mathrm{~mL} /(\mathrm{g} \cdot \mathrm{h}) \mathrm{SV}$ & R.T. & [69] \\
\hline Ag-HMO & 400 ppm HCHO, 10 vol $\% \mathrm{O}_{2}, 30000 \mathrm{~mL} /(\mathrm{g} \cdot \mathrm{h}) \mathrm{SV}$ & 80 & {$[70,71]$} \\
\hline $3 \mathrm{DOM} \mathrm{Au} / \mathrm{CeO}_{2}$ & $0.06 \% \mathrm{HCHO}, 66000 \mathrm{~mL} /(\mathrm{g} \cdot \mathrm{h}) \mathrm{SV}$ & 70 & {$[72,73]$} \\
\hline $3 \mathrm{DOM} \mathrm{Au} / \mathrm{CeO}_{2}-\mathrm{Co}_{3} \mathrm{O}_{4}$ & $0.06 \%$ HCHO (8ppm), $15000 \mathrm{~mL} /(\mathrm{g} \cdot \mathrm{h}) \mathrm{SV}$ & R.T. & [74] \\
\hline $3 \mathrm{DOM} \mathrm{Au} / \mathrm{CeO}_{2}$ & & 42 & \\
\hline $3 \mathrm{DOM} \mathrm{Au} / \mathrm{Co}_{3} \mathrm{O}_{4}$ & & 30 & \\
\hline $2 \mathrm{D} \mathrm{Au} / \mathrm{Co}_{3} \mathrm{O}_{4}-\mathrm{CeO}_{2}$ & $200 \mathrm{ppm} \mathrm{HCHO}, 22 \mathrm{vol} \% \mathrm{O}_{2}, 55000 \mathrm{~h}^{-1} \mathrm{SV}$ & R.T. & [75] \\
\hline $2 \mathrm{D} \mathrm{Au} / \mathrm{Co}_{3} \mathrm{O}_{4}$ & & R.T. & \\
\hline $2 \mathrm{D} \mathrm{Au} / \mathrm{CeO}_{2}$ & & - & \\
\hline Mesoporous $\mathrm{Au} / \mathrm{ZrO}_{2}$ & $90 \mathrm{mg} / \mathrm{m}^{3} \mathrm{HCHO}, 52000 \mathrm{~mL} /(\mathrm{g} \cdot \mathrm{h}) \mathrm{SV}$ & 120 & [77] \\
\hline $3 \mathrm{D} \mathrm{Ag} / \mathrm{Co}_{3} \mathrm{O}_{4}$ & $100 \mathrm{ppm}$ HCHO, 20 vol\% $\mathrm{O}_{2}, 30000 \mathrm{~h}^{-1} \mathrm{SV}$ & $<80$ & [78] \\
\hline $3 \mathrm{D} \mathrm{K}-\mathrm{Ag} / \mathrm{Co}_{3} \mathrm{O}_{4}$ & & R.T. & \\
\hline $\mathrm{Ag} / \mathrm{CeO}_{2}$ nanospheres & 810 ppm HCHO, 20 vol\% $\mathrm{O}_{2}, 84000 \mathrm{~h}^{-1} \mathrm{SV}$ & 90 & [79] \\
\hline $\mathrm{Ag} / \mathrm{CeO}_{2}$ bulk particles & & 140 & \\
\hline Pt-Ce/OMS-2 & $500 \mathrm{ppm}$ HCHO, 10 vol\% $\mathrm{O}_{2}, 30000 \mathrm{~mL} /(\mathrm{g} \cdot \mathrm{h}) \mathrm{SV}$ & 120 & [80] \\
\hline Pt/OMS-2 & & 100 & \\
\hline
\end{tabular}

nanospheres, and nanoporous materials; these have better catalytic activities than the corresponding traditional bulk metal oxides. These materials, e.g., $\mathrm{MnO}_{2}$ nanorods or nanospheres, $\mathrm{CeO}_{2}$ nanospheres, mesoporous $\mathrm{Co}_{3} \mathrm{O}_{4}$, and macroporous $\mathrm{CeO}_{2}$, are metal oxide supports with special morphologies. Table 1 gives an overview of the catalytic activities in HCHO oxidation of various supported noble-metal catalysts.

\subsection{Common supports}

Common supports used in $\mathrm{HCHO}$ oxidation are materials such as $\mathrm{SiO}_{2}, \mathrm{Al}_{2} \mathrm{O}_{3}, \mathrm{TiO}_{2}$, and molecular sieves. Noble-metal catalysts are often prepared by loading $\mathrm{Pt}, \mathrm{Pd}, \mathrm{Rh}, \mathrm{Ru}, \mathrm{Au}$, and Ag on common carriers with large surface areas.

Zhang et al. [44,45] reported $\mathrm{TiO}_{2}$-supported noble-metal (Pt, Rh, Pd, and $\mathrm{Au}$ ) catalysts. The order of the HCHO oxidation activities over $\mathrm{TiO}_{2}$-supported noble-metal catalyst was $\mathrm{Pt} / \mathrm{TiO}_{2}>\mathrm{Rh} / \mathrm{TiO}_{2}>\mathrm{Pd} / \mathrm{TiO}_{2}>\mathrm{Au} / \mathrm{TiO}_{2}$. Complete HCHO conversion to $\mathrm{CO}_{2}$ and $\mathrm{H}_{2} \mathrm{O}$ was achieved over $1 \% \mathrm{Pt} / \mathrm{TiO}_{2}$ at $20{ }^{\circ} \mathrm{C}$ at a gas hourly space velocity (GHSV) of $50000 \mathrm{~h}^{-1}$ (Fig. 1). High Pt dispersion is an important reason for the high activities. Based on the results achieved using a $1 \% \mathrm{Pt} / \mathrm{TiO}_{2}$ catalyst, this research group also prepared $2 \% \mathrm{Na}-1 \% \mathrm{Pt} / \mathrm{TiO}_{2}$ using $\mathrm{Na}^{+}$ ions as auxiliaries [46]. This catalyst has the best catalytic activity and stability reported to date for HCHO oxidation, and complete conversion is achieved at room temperature for 600 ppm HCHO and a GHSV of $300000 \mathrm{~h}^{-1}$ (Fig. 2). The activity is high because $\mathrm{Na}^{+}$ions generate surface hydroxyl groups for oxidation, and the presence of surface hydroxyl groups changes the reaction mechanism. Nie et al. [47] reported $\mathrm{Pt} / \mathrm{TiO}_{2}$ cata-

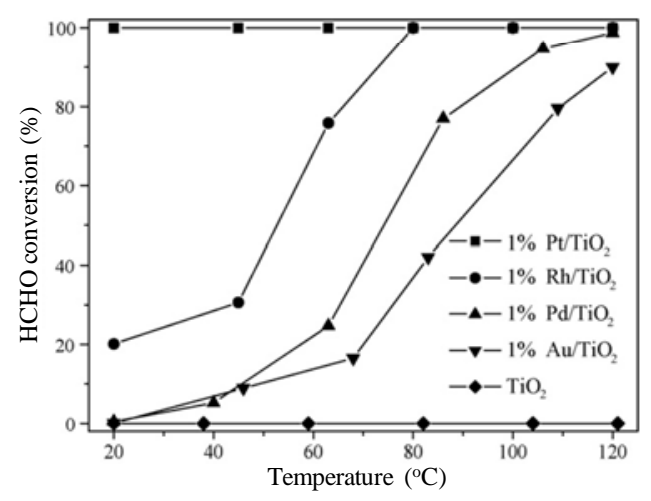

Fig. 1. $\mathrm{HCHO}$ conversions on $\mathrm{TiO}_{2}$-supported $1 \mathrm{wt} \%$ noble-metal $(\mathrm{Pt}$, $\mathrm{Rh}, \mathrm{Pd}$, and $\mathrm{Au}$ ) catalysts at various temperatures [45]. Reaction conditions: $\mathrm{HCHO} 100 \mathrm{ppm}, \mathrm{O}_{2} 20 \mathrm{vol} \%$, He balance, total flow rate 50 $\mathrm{mL} / \mathrm{min}$, GHSV $50000 \mathrm{~h}^{-1}$. 


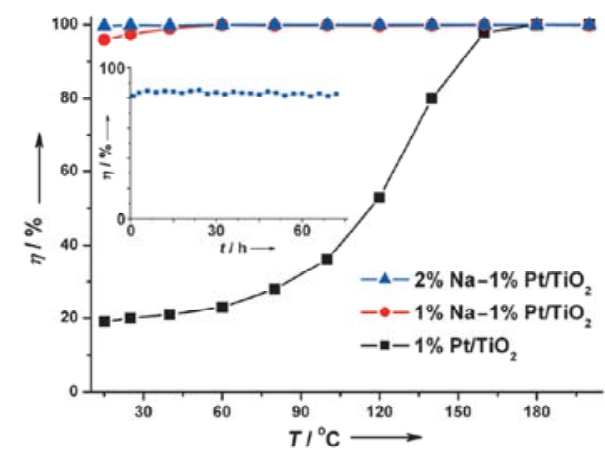

Fig. 2. $\mathrm{HCHO}$ conversions over $\mathrm{Na}-\mathrm{Pt} / \mathrm{TiO}_{2}$ catalysts [46]. Reaction conditions: $\mathrm{HCHO} 600 \mathrm{ppm}, \mathrm{O}_{2} 20 \mathrm{vol} \%$, relative humidity $50 \%$, He balance, total flow rate $50 \mathrm{~mL} / \mathrm{min}$, and GHSV $120000 \mathrm{~h}^{-1}$ (inset: $2 \%$ $\mathrm{Na}-1 \% \mathrm{Pt} / \mathrm{TiO}_{2}$ stability test at $25{ }^{\circ} \mathrm{C}$, GHSV $300000 \mathrm{~h}^{-1}$, other reaction conditions the same).

lysts with various Pt loadings (0.05-2 wt\%). They tested their catalytic performances in $\mathrm{HCHO}$ oxidation in the presence of toluene. $\mathrm{HCHO}$ was selectively oxidized to $\mathrm{CO}_{2}$ and $\mathrm{H}_{2} \mathrm{O}$ by the $\mathrm{Pt} / \mathrm{TiO}_{2}$ catalysts, and toluene did not affect the catalytic reaction. $\mathrm{Pt} / \mathrm{TiO}_{2}$ catalysts prepared with the assistance of $\mathrm{NaOH}$ showed higher HCHO oxidation activities than those without $\mathrm{NaOH}$ because of the presence of surface hydroxyl groups, high adsorption capacity, and large mesopores and macropores, which facilitate diffusion and transport of reactants and products. Kim et al. [48] reported HCHO oxidation at room temperature on $\mathrm{Pt} / \mathrm{TiO}_{2}$ catalysts. The results show that the catalytic activity depends on the type of $\mathrm{TiO}_{2}$ carrier, metal valence state of the catalyst, and $\mathrm{HCHO}$ feed rate. $\mathrm{CO}$ is the main intermediate species in HCHO oxidation. An et al. [49] prepared $\mathrm{Pt} / \mathrm{SiO}_{2}$ and Pt/SBA-15 catalysts; these completely converted HCHO at room temperature and $50{ }^{\circ} \mathrm{C}$, respectively. The use of $\mathrm{SiO}_{2}$ as a carrier may affect the particle size and chemical valence of $\mathrm{Pt}$ species, and this can be favorable to redox reactions of $\mathrm{Pt} / \mathrm{SiO}_{2}$. Peng et al. [50] also prepared supported noble-metal (Pt, Pd, $\mathrm{Rh})$ catalysts. The activity order over $\mathrm{TiO}_{2}$-based catalysts was $\mathrm{Pt} / \mathrm{TiO}_{2}>\mathrm{Pd} / \mathrm{TiO}_{2}>\mathrm{Rh} / \mathrm{TiO}_{2}$. The activity order for various supports loaded with $\mathrm{Pt}$ was $\mathrm{TiO}_{2}>\mathrm{SiO}_{2}>\mathrm{CeZrO}_{2}$. Chuang et al. [51] proposed a reaction mechanism for $\mathrm{HCHO}$ oxidation over a Pt catalyst supported on hydrophobic fluorinated carbon. HCHO conversion $\left(T_{50}\right)$ over the $\mathrm{Pt} /$ carbon catalyst was achieved below $100{ }^{\circ} \mathrm{C}$. Huang et al. [52] prepared Pt/TiO ${ }_{2}$ catalysts and examined the effects of metal oxidation state, carrier, and Pt particle size on the catalytic performance in HCHO oxidation. A catalyst consisting of $0.1 \mathrm{wt} \% \mathrm{Pt} / \mathrm{TiO}_{2}$ had excellent activity in $\mathrm{HCHO}$ oxidation, because the reduction of Pt particles increased electron mobility and the number of reactive oxygen species. This group also prepared $\mathrm{Pd} / \mathrm{TiO}_{2}$ catalysts [53]. These catalysts gave better catalytic performances in HCHO oxidation, with turnover frequencies (TOFs) of $0.015 \mathrm{~s}^{-1}$ at room temperature. Strong metal-support interactions, well-dispersed and negatively charged metallic Pd nanoparticles, and large amounts of chemically adsorbed oxygen are probably responsible for the high catalytic activities. In the reaction, Pd nanoparticles provide active sites for HCHO oxida- tion, and promote oxygen activation. Park et al. [54] prepared a series of Pd catalysts supported on Bata, USY, ZSM-5, HM10, and Zeo-13X molecular sieves. Pd/ZSM-5 Pd/Bata, Pd/USY, $\mathrm{Pd} / \mathrm{HM}$, and $\mathrm{Pd} / \mathrm{Zeo}-13 \mathrm{X}$ all have good HCHO catalytic activities at low temperatures $\left(T_{50}<40{ }^{\circ} \mathrm{C}\right)$. The catalytic performance in $\mathrm{HCHO}$ oxidation of the Pd/Bata catalyst was slightly better than those of the others. Formate and dioxymethylene are the main intermediates in the reaction, and these are the surface species involved in HCHO oxidation. dela O'Shea et al. [55] prepared a $\mathrm{Pd}-\mathrm{Mn} / \mathrm{Al}_{2} \mathrm{O}_{3}$ catalyst, and investigated the effect of feed concentration on its catalytic performance in $\mathrm{HCHO} /$ methanol oxidation. Its catalytic activity was low because of decomposition of $\mathrm{PdO}$ to $\mathrm{Pd}$ and $\mathrm{MnO}_{2} / \mathrm{Mn}_{2} \mathrm{O}_{3}$ to $\mathrm{Mn}_{3} \mathrm{O}_{4}$. There were fewer oxygen species available for transfer to $\mathrm{Pd}^{0}$. In addition, after water vapor addition, catalyst passivation resulted in competition between water and VOC molecules for active sites. Qu et al. [56] investigated the oxidation of HCHO on a Ag/SBA-15 catalyst. The catalyst completely converted $\mathrm{HCHO}$ at $100{ }^{\circ} \mathrm{C}$ at a GHSV of $15000 \mathrm{~mL} /(\mathrm{g} \cdot \mathrm{h}$ ) (Table 1). This is attributed to higher $\mathrm{Ag}$ dispersion in the narrow pores of SBA-15 and high HCHO adsorption. Ag nanoparticles provide active sites for oxidation. In the absence of $\mathrm{Ag}$, $\mathrm{HCHO}$ is only converted to formate and dioxymethylene. Mao et al. [57] prepared $\mathrm{Ag} / \mathrm{Al}_{2} \mathrm{O}_{3}$ and $\mathrm{Ag} / \mathrm{SiO}{ }_{2}$ catalysts, and clarified the mechanism of HCHO oxidation. The formation of $\mathrm{CO}_{2}$ and $\mathrm{CO}$ is attributed to the decomposition of formate on the catalyst surface, and the formation of formate is attributed to the reaction of dioxymethylene.

Noble metals loaded on common supports with large surface areas have an excellent catalytic activity. This is related to the specific surface areas of the supports, noble-metal dispersion, active sites, particle size, valence state, and adsorption ability. A large surface area increases exposure of a large number of active sites and the adsorption and diffusion of reactants and products, and can enhance the synergistic effect between the support and the active component. Table 1 shows that the catalytic activities in HCHO oxidation of various noble metals loaded on common supports decrease in the following order: $\mathrm{Pt}$ $>\mathrm{Pd}>\mathrm{Rh}>\mathrm{Au}>\mathrm{Ag}$. Pt/TiO 2 [45], and $\mathrm{Pd} / \mathrm{TiO}_{2}$ [53] can completely convert $\mathrm{HCHO}$ at room temperature. $\mathrm{Na}-\mathrm{Pt} / \mathrm{TiO}_{2}$ is the best catalyst for HCHO removal [46]. Generally, use of a different support but the same active components affects the catalytic activity. For example, Imamura et al. [58] reported the oxidation of HCHO over supported noble-metal catalysts. HCHO conversions $\left(T_{50}\right)$ using $\mathrm{Ru} / \mathrm{Al}_{2} \mathrm{O}_{3}, \mathrm{Ru} /$ zeolite, and $\mathrm{Ru} / \mathrm{TiO}_{2}$ were achieved at 198,210 , and $212{ }^{\circ} \mathrm{C}$, respectively, and conversion with $\mathrm{Ru} / \mathrm{CeO}_{2}$ was obtained below $150{ }^{\circ} \mathrm{C}$. The $\mathrm{HCHO}$ oxidation activity of $\mathrm{Ru} / \mathrm{CeO}_{2}$ is better than those of $\mathrm{Ru} / \mathrm{Al}_{2} \mathrm{O}_{3}$, $\mathrm{Ru} /$ zeolite, and $\mathrm{Ru} / \mathrm{TiO}_{2}$. For $\mathrm{CeO}_{2}$ loaded with $\mathrm{Ru}, \mathrm{Pd}, \mathrm{Rh}, \mathrm{Pt}$, and $\mathrm{Ir}$, the order of the catalytic activities $\left(T_{90}\right)$ is $\mathrm{Ru} / \mathrm{CeO}_{2}>$ $\mathrm{Pd} / \mathrm{CeO}_{2}>\mathrm{Rh} / \mathrm{CeO}_{2}>\mathrm{Ir} / \mathrm{CeO}_{2}>\mathrm{Pt} / \mathrm{CeO}_{2}$. The better $\mathrm{HCHO}$ oxidation activity of the $\mathrm{Ru} / \mathrm{CeO}_{2}$ catalyst indicates that other noble metals, as well as $\mathrm{Pt}$ and $\mathrm{Pd}$, may have potential catalytic applications if an appropriate common support is used.

\subsection{Traditional metal oxide supports}

Catalysts that have the advantages of both precious-metal 
and metal oxide catalysts can be obtained by loading precious metals on metal oxide supports. Such catalysts have better low-temperature oxidation activities and thermostabilities, and enhanced interactions between the metal and the support. Sekizawl et al. [59] reported a $\mathrm{Pd} / \mathrm{SnO}_{2}$ catalyst. The results show that the catalyst has a lower specific surface area, but better hydrothermal stability than a $\mathrm{Pd} / \mathrm{Al}_{2} \mathrm{O}_{3}$ catalyst. Minico et al. [60] reported that $\mathrm{Au}$ nanoparticles can produce synergies with $\mathrm{CeO}_{2}$ and $\mathrm{Fe}_{2} \mathrm{O}_{3}$, reduce the combining capacities of oxygen, $\mathrm{Ce}$, and $\mathrm{Fe}$, strengthen the interactions between $\mathrm{Au}$ and the support, and promote reactions with surface oxygen species.

Traditional metal oxide supports for the catalytic oxidation of $\mathrm{HCHO}$, such as $\mathrm{CeO}_{2}, \mathrm{Fe}_{2} \mathrm{O}_{3}, \mathrm{Co}_{3} \mathrm{O}_{4}$, and $\mathrm{MnO}_{2}$, or their composites, are usually prepared by precipitation, coprecipitation, or sol-gel methods. Imamura et al. [58,61] reported that supported noble-metal $(\mathrm{Ag}, \mathrm{Ru}, \mathrm{Pd}, \mathrm{Rh}$, and $\mathrm{Pt}$ ) catalysts all displayed activity in $\mathrm{HCHO}$ oxidation below $150{ }^{\circ} \mathrm{C}$. Tang et al. [62] prepared $\mathrm{Pt} / \mathrm{MnO}_{x}-\mathrm{CeO}_{2}$ catalysts and examined the effects of the two precursors on the HCHO oxidation performance. The results show that the activity and stability of the Pt-containing catalyst prepared from $\mathrm{Pt}\left(\mathrm{NH}_{3}\right)_{2}\left(\mathrm{NO}_{2}\right)_{2}$ are better than those of the catalyst prepared from $\mathrm{H}_{2} \mathrm{PtCl}_{6}$. It can completely oxidize $\mathrm{HCHO}$ at room temperature because of effective activation of oxygen molecules on the $\mathrm{MnO}_{x}-\mathrm{CeO}_{2}$ carrier. $\mathrm{A} \mathrm{Ag} / \mathrm{MnO}_{x}-\mathrm{CeO}_{2}$ catalyst was also prepared [63]. Its $\mathrm{HCHO}$ oxidation activity (Table 1) is better than those of $\mathrm{Ag} / \mathrm{MnO}_{x}$ and $\mathrm{Ag} / \mathrm{CeO}$. This is attributed to formation of $\mathrm{MnO}_{x}-\mathrm{CeO}_{2}$ solid solution and $\mathrm{Ag}_{2} \mathrm{O}$ oxygen species produced from a $\mathrm{Mn}^{4+} / \mathrm{Mn}^{3+}$ and $\mathrm{Ce}^{4+} / \mathrm{Ce}^{3+}$ redox cycle. Shen et al. [64] reported a series of $\mathrm{Au} / \mathrm{CeO}_{2}$ catalysts in which $\mathrm{Au}$ clusters are dispersed on the catalyst surfaces. When the Au content is $0.78 \%$, the Au particle size is about 10 $\mathrm{nm}$. The results show that large Au particles are not beneficial to catalytic oxidation. Highly dispersed Au crystallite clusters can provide more active sites for HCHO oxidation. Li et al. [65] also reported the catalytic oxidation of $\mathrm{HCHO}$ on $\mathrm{Au} / \mathrm{CeO}_{2}$. An increase in the specific surface area enhanced the catalytic ability. The catalyst has better oxidation activity for two reasons. One is the high valence of $\mathrm{Au}$ species on the $\mathrm{CeO}_{2}$ surface, the other is formation of oxygen vacancies and $a \mathrm{Au}_{x} \mathrm{Ce}_{1-x} \mathrm{O}_{2-\delta}$ solid solution. Li et al. [66] prepared a catalyst with $\mathrm{Au}$ as the active component and iron oxide as the carrier. The HCHO oxidation activity of the $7.10 \% \mathrm{Au} / \mathrm{Fe}-\mathrm{O}$ catalyst $\left(T_{50}=40{ }^{\circ} \mathrm{C}\right.$, Table 1$)$ was the best. This is attributed to the presence of $\mathrm{Au}^{\delta+}$ and active species that play an important role in the reaction. An et al. [67] reported that $\mathrm{Pt} / \mathrm{Fe}_{2} \mathrm{O}_{3}$ catalysts after calcination at 200 and $300{ }^{\circ} \mathrm{C}$ have good activities and stabilities. HCHO can be completely converted at room temperature. This is attributed to interactions between $\mathrm{Pt}$ and $\mathrm{Fe}_{2} \mathrm{O}_{3}$ to form $\mathrm{Pt}-\mathrm{O}-\mathrm{Fe}$ bonds, which are favorable for oxidation. Tian et al. [68] prepared K-OMS-2 using a sol-gel method and loaded Pt and Ag on it using a conventional impregnation method. Unlike the cases for other reported catalysts such as $\mathrm{Pt} / \mathrm{MnO}_{2}$ [69] and $\mathrm{Ag} / \mathrm{MnO}_{2}$ [70], the addition of Pt or Ag reduced the catalytic activity. The order of the catalytic activities in HCHO oxidation was $\mathrm{K}-\mathrm{OMS}-2$ > Pt/K-OMS > Ag/K-OMS. HCHO conversion of $50 \%$ was achieved over $\mathrm{K}-\mathrm{OMS}-2$ at $180^{\circ} \mathrm{C}$.
Among the catalysts of this type listed in Table 1, supported $\mathrm{Pt}$ catalysts have excellent catalytic activities $\left(T_{50}\right)$ at room temperature. However, some catalysts such as $\mathrm{Au} / \mathrm{CeO}_{2}$, $\mathrm{Ag} / \mathrm{MnO}_{x}-\mathrm{CeO}_{2}$, and $\mathrm{Ag} / \mathrm{CeO}_{2}$ have better development potential, with $\mathrm{HCHO}$ conversions $\left(T_{50}\right)$ achieved below $40{ }^{\circ} \mathrm{C}$ on $\mathrm{Au} / \mathrm{CeO}_{2}$ [65], at $70{ }^{\circ} \mathrm{C}$ on $\mathrm{Ag} / \mathrm{MnO}_{x}-\mathrm{CeO}_{2}$, and at $90{ }^{\circ} \mathrm{C}$ on $\mathrm{Ag} / \mathrm{CeO}_{2}$ [63]. These results are attributed to stronger interactions between the noble metal and the support, and special crystalline structures with solid solutions. The choice of support is very important for the catalytic activity in HCHO oxidation. The same $\mathrm{Au} / \mathrm{CeO}_{2}$ catalysts $[64,65]$, but with different specific surface areas, show different catalytic activities. $\mathrm{Au} / \mathrm{CeO}_{2}$ with a higher surface area clearly has better oxidation activity $\left(T_{50}<40^{\circ} \mathrm{C}\right)$; the surface area is related to the preparation method. A range of supports are available for supported noble-metal catalysts. Many studies have confirmed that supported Pt catalysts are promising, but limited by the cost of Pt, therefore Pt may not be the best choice as the active component for HCHO removal. Some supported $\mathrm{Au}$ and Ag catalysts could be used as alternatives to Pt catalysts. The metal oxide supports can also be modified by using different preparation methods.

\subsection{Metal oxide supports with special morphologies}

Catalysts supported on metal oxides with special morphologies, which are mainly prepared using hydrothermal and hard template methods, have higher catalytic activities than those supported on conventional bulk metal oxides prepared using precipitation methods. Catalysts with specific morphologies, based on noble metals supported on metal oxides with special morphologies, are better able to remove HCHO at low temperatures, even room temperature, than catalysts with traditional metal oxide supports. Many metal oxides with special morphologies such as tubes, lines, rods, sheets, flowers, spheres, cubes, and pores have been reported, but only metal oxide supports with morphologies involving rods, spheres, mesopores, and macropores have been used in catalytic oxidation of HCHO.

Yu et al. [69] reported a Pt/ $\mathrm{MnO}_{2}$ catalyst with good $\mathrm{HCHO}$ oxidation activity. Pt nanoparticles were evenly dispersed on the surfaces of $\mathrm{MnO}_{2}$ nanospheres. The addition of Pt clearly reduced the reaction temperature. The Pt dispersion, grain size, and interactions between $\mathrm{Pt}$ and $\mathrm{MnO}_{2}$ are the main reasons for the good catalytic activity in HCHO oxidation. Tang's group [70] reported a Ag-hollandite manganese oxide (HMO) catalyst with single Ag atoms as active sites. The HMO nanorods consist of one-dimensional $0.47 \times 0.47 \mathrm{~nm}^{2}$ square tunnels, and the basic unit of the tunnel structure is built from eight $(4+4)$ oxygen atoms to form a tetragonal prism. Each of the eight oxygen atoms in the tunnels has four $\mathrm{sp}^{3}$-hybridized orbitals, three of which bond to three $\mathrm{Mn}^{4+}$ cations and the other, occupied by lone-pair electrons, points to the central axis of the tunnel. Theoretically, linear tunnels of a specific size and electron-rich tunnel oxygen atoms can serve as a natural mold and an electron donor, respectively; this favors formation of stable single-atom Ag chains in the HMO tunnels. The single Ag atoms 

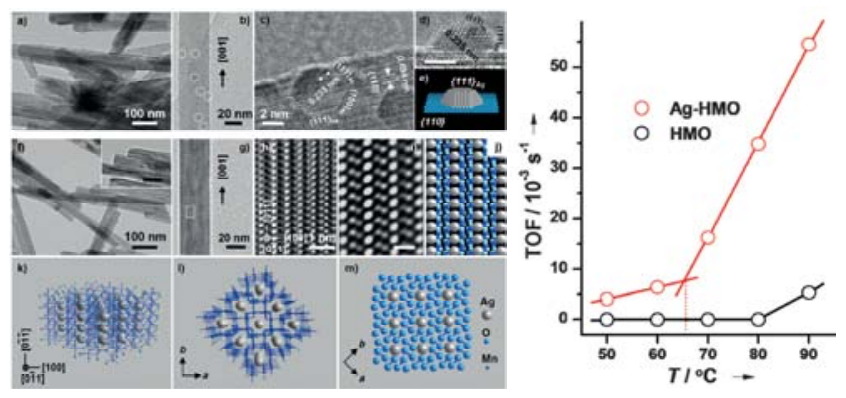

Fig. 3. TEM and high-resolution TEM images and corresponding structural models of Ag-HMO; TOFs for HCHO oxidation over Ag-HMO are taken from Ref. [70].

anchored at the openings of the Ag-HMO tunnel nanorods are active sites, and can easily activate lattice oxygen and molecular oxygen. The Ag-HMO structure is shown in Fig. 3. The activation of oxygen species results in excellent HCHO oxidation activity at low temperatures. The Ag-HMO catalyst has a high TOF, $0.054 \mathrm{~s}^{-1}$, at $90^{\circ} \mathrm{C}$ and HCHO conversion $\left(T_{50}\right)$ is achieved at $80{ }^{\circ} \mathrm{C}$ (Table 1). This group also examined the atomic $\mathrm{Ag}$ centers [71]. Zhang et al. [72] prepared three-dimensional ordered macroporous (3DOM) $\mathrm{Au} / \mathrm{CeO}_{2}$ with controlled pore sizes. Fig. 4 shows scanning electron microscopy (SEM) and transmission electron microscopy (TEM) images, and $\mathrm{HCHO}$ conversions for $3 \mathrm{DOM} 1 \mathrm{wt} \% \mathrm{Au} / \mathrm{CeO}_{2}$ prepared using $\mathrm{CeO}_{2}$ of pore size $80 \mathrm{~nm}$. The catalyst has interconnected networks of spherical voids. Au nanoparticles are uniformly dispersed on the surface. The catalytic activity of 3DOM $1 \mathrm{wt} \% \mathrm{Au} / \mathrm{CeO}_{2}$ in $\mathrm{HCHO}$ oxidation is excellent and complete conversion of 0.06 vol\% HCHO is achieved at $75{ }^{\circ} \mathrm{C}$. This temperature is lower than that needed for complete conversion using non-porous $\mathrm{Au} / \mathrm{CeO}_{2}$. The better activity of 3DOM Au/CeO 2 in $\mathrm{HCHO}$ oxidation is the result of $\mathrm{Au}$ dispersion, a higher $\mathrm{Au}$ content, and the presence of $\mathrm{Au}^{3+}$. This group also reported the mechanism of $\mathrm{HCHO}$ oxidation on the $3 \mathrm{DOM} \mathrm{Au} / \mathrm{CeO}_{2}$ catalyst [73]. $\mathrm{HCHO}$ molecules are adsorbed to form formate species on the catalyst surface. The adsorption and activation of oxygen species are related to the $\mathrm{Au}^{3+} / \mathrm{Au}^{0}$ and $\mathrm{Ce}^{4+} / \mathrm{Ce}^{3+}$ redox cycles. During $\mathrm{HCHO}$ oxidation, formate species are further oxidized to $\mathrm{CO}_{2}$ and $\mathrm{H}_{2} \mathrm{O}$ by active oxygen species. If the formate is not completely oxidized, carbonate or bicarbonate is produced on the $3 \mathrm{DOM} \mathrm{Au} / \mathrm{CeO}_{2}$ surface, and may cause catalyst passivation. However, it is difficult to block the active sites on the catalyst
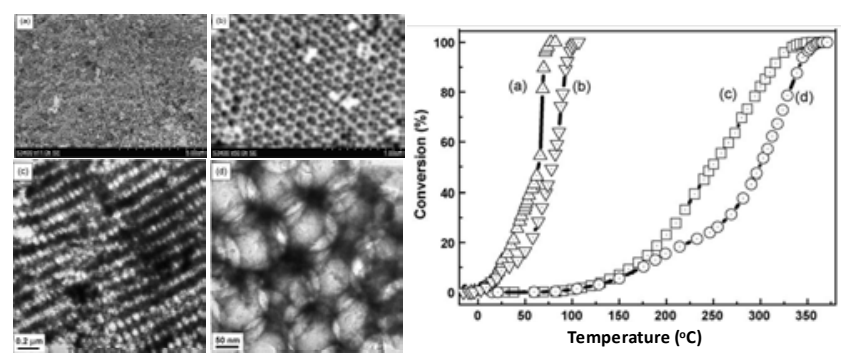

Fig. 4. SEM and TEM images of 3DOM $\mathrm{Au} \sim 1 \mathrm{wt} \% / \mathrm{CeO}_{2}$; $\mathrm{HCHO}$ conversions of (a) 3DOM Au $\sim 1 \mathrm{wt} \% / \mathrm{CeO}_{2}$ ( $80 \mathrm{~nm}$ pore size), (b) 3DOM Au $\sim 1$ $\mathrm{wt} \% / \mathrm{CeO}_{2}$ (130 nm pore size), (c) $3 \mathrm{DOM} \mathrm{CeO}_{2}$ (80 nm pore size), (d) $3 \mathrm{DOM} \mathrm{CeO}_{2}$ (130 nm pore size) from Ref. [72]. surface because of the large and open pores. A 3DOM $\mathrm{Au} / \mathrm{CeO}_{2}-\mathrm{Co}_{3} \mathrm{O}_{4}$ catalyst was prepared by this group, based on $3 \mathrm{DOM} \mathrm{Au} / \mathrm{CeO}_{2}$ [74]. HCHO can be completely converted at 39 ${ }^{\circ} \mathrm{C}$. The interactions between $\mathrm{CeO}_{2}$ and $\mathrm{Co}_{3} \mathrm{O}_{4}$ promote the migration of surface oxygen species and activation of $\mathrm{Au}$ species. Ma et al. [75] reported that two-dimensional (2D) ordered mesoporous $\mathrm{Au} / \mathrm{Co}_{3} \mathrm{O}_{4}-\mathrm{CeO}_{2}$ had good catalytic activity in HCHO oxidation, with $50 \%$ HCHO conversion at room temperature (Table 1). The catalytic activity decreases with increasing $\mathrm{CeO}_{2}$ content. The (110) crystal planes of $\mathrm{Co}_{3} \mathrm{O}_{4}$ are the main active faces, and they can adsorb and activate HCHO species. $\mathrm{Au}$ loading facilitates the formation of surface oxygen species. This group also prepared a similar $3 \mathrm{D} \mathrm{Au} / \mathrm{Co}_{3} \mathrm{O}_{4}$ catalyst for the elimination of ethylene, and a better catalytic performance was obtained [76]. Zhang et al. [77] prepared mesoporous $\mathrm{Au} / \mathrm{ZrO}_{2}$ for $\mathrm{HCHO}$ oxidation. The $\mathrm{Au}$ is better dispersed, with more $\mathrm{Au}^{3+}$

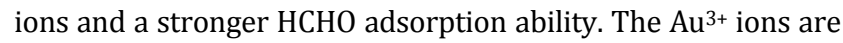
reduced to $\mathrm{Au}^{0}$ metal, and adsorbed $\mathrm{HCHO}$ molecules are quickly converted to formate species. A catalysts consisting of $0.85 \mathrm{wt} \% \mathrm{Au} / \mathrm{ZrO}_{2}$ can completely convert $\mathrm{HCHO}$ at $180{ }^{\circ} \mathrm{C}$ because of adsorption of $\mathrm{HCHO}$ on $\mathrm{Au}$ species and of oxygen molecules on the support.

Our group used KIT- 6 mesoporous silica as a hard template to prepare 3D ordered $\mathrm{Co}_{3} \mathrm{O}_{4}$ [42]. Mesoporous metal oxides have potential as catalysts. Mesoporous $\mathrm{Ag} / \mathrm{Co}_{3} \mathrm{O}_{4}$ and $\mathrm{K}-\mathrm{Ag} / \mathrm{Co}_{3} \mathrm{O}_{4}$ catalysts based on $3 \mathrm{D} \mathrm{Co}_{3} \mathrm{O}_{4}$ were prepared [78]. Ag nanoparticles were uniformly dispersed and supported on a polycrystalline wall. The addition of $\mathrm{K}^{+}$ions strengthens anionic lattice defects and interactions between $\mathrm{Ag}$ and the $\mathrm{Co}_{3} \mathrm{O}_{4}$ support, resulting in formation of more $\mathrm{Co}^{3+}$ ions and surface lat-

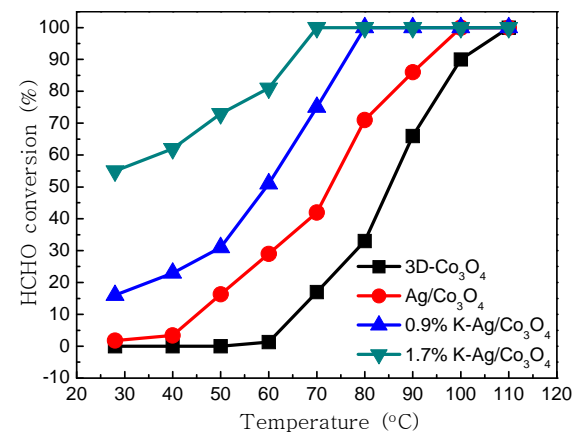

Fig. 5. $\mathrm{HCHO}$ conversion over $\mathrm{K}-\mathrm{Ag} / \mathrm{Co}_{3} \mathrm{O}_{4}$ catalyst [78].
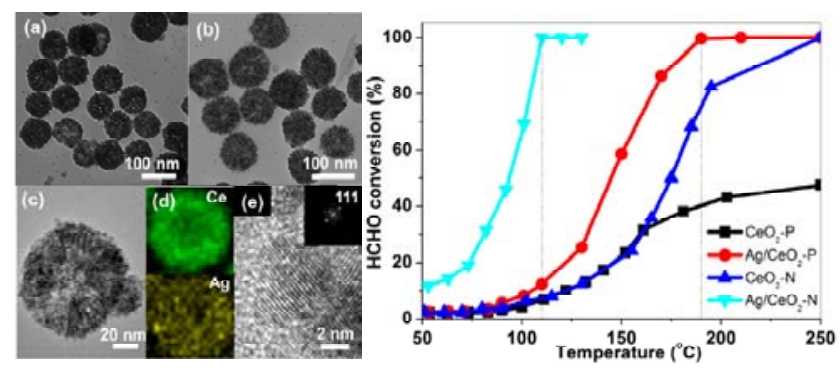

Fig. 6. TEM image of (a) $\mathrm{CeO}_{2}-\mathrm{N}$ nanosphere, (b) $\mathrm{Ag} / \mathrm{CeO}_{2}-\mathrm{N}$ nanosphere, (c) $\mathrm{Ag} / \mathrm{CeO}_{2}-\mathrm{N}$ nanosphere, (e) $\mathrm{Ag} / \mathrm{CeO}_{2}-\mathrm{N}$ nanosphere and (d) the distribution of element maps of Ce (green) and $\mathrm{Ag}$ (yellow) on $\mathrm{Ag} / \mathrm{CeO}_{2}-\mathrm{N}$ nanosphere and $\mathrm{HCHO}$ conversions over $\mathrm{Ag} / \mathrm{CeO}_{2}$ nanospheres [79]. 
tice oxygen species. The catalytic activity in $\mathrm{HCHO}$ oxidation of the $\mathrm{K}-\mathrm{Ag} / \mathrm{Co}_{3} \mathrm{O}_{4}$ sample is better than that of the $\mathrm{Ag} / \mathrm{Co}_{3} \mathrm{O}_{4}$ catalyst because of the presence of surface hydroxyl species and exposure of Ag (111) active faces. HCHO conversion of $50 \%$ was achieved at room temperature using $\mathrm{K}-\mathrm{Ag} / \mathrm{Co}_{3} \mathrm{O}_{4}$ (Fig. 5). Our group reported catalysts with Ag nanoparticles loaded on $\mathrm{CeO}_{2}$ nanospheres and bulk particles [79]. Fig. 6 shows TEM images of the $\mathrm{Ag} / \mathrm{CeO}_{2}$ nanospheres and the achieved HCHO conversions. The catalytic activity in HCHO oxidation of $\mathrm{Ag} / \mathrm{CeO}_{2}$ nanospheres is better than that of $\mathrm{Ag} / \mathrm{CeO}_{2}$ bulk particles. $\mathrm{Ag} / \mathrm{CeO}_{2}$ nanospheres can completely convert $810 \mathrm{ppm} \mathrm{HCHO}$ at $110^{\circ} \mathrm{C}$ and a GHSV of $84000 \mathrm{~h}^{-1}$; the HCHO conversion $\left(T_{50}\right)$ at $90{ }^{\circ} \mathrm{C}$ is shown in Table 1 . The reaction rate is almost 3.6 times that obtained with $\mathrm{Ag} / \mathrm{CeO}_{2}$ bulk particles. The average $\mathrm{Ag} / \mathrm{CeO}_{2}$ nanosphere size is between 80 and $100 \mathrm{~nm}$, and it consists of small crystallites of size 2-5 nm. This special structure promotes good distribution of $\mathrm{Ce}$ and $\mathrm{Ag}$. Oxygen is easily chemisorbed on the $\mathrm{Ag} / \mathrm{CeO}_{2}$ nanosphere surfaces, and interactions between $\mathrm{Ag}$ and $\mathrm{CeO}_{2}$ may occur in the catalyst. Our group also reported that the catalytic activity of $\mathrm{Pt}-\mathrm{Ce} / \mathrm{OMS}-2$ in HCHO oxidation [80] was lower than those over $\mathrm{Ag}-\mathrm{HMO}$ [70], $\mathrm{K}-\mathrm{Ag} / \mathrm{Co}_{3} \mathrm{O}_{4}$ [78], and $\mathrm{Ag}-\mathrm{CeO}_{2}$ nanospheres [79].

Table 1 shows that metal oxide supports with special structures have rarely been used for Pt loading, except Pt/nest-like $\mathrm{MnO}_{2}$ [69] and Pt/OMS-2 [80]. This is because 2\% $\mathrm{Na}-1 \%$ $\mathrm{Pt} / \mathrm{TiO}_{2}$ has become the benchmark for supported Pt catalysts, and is used in air purification. More attention has been paid to

Table 2

Overview of catalytic activities of transition-metal oxides in HCHO oxidation.

\begin{tabular}{|c|c|c|c|}
\hline Catalysts & Reaction conditions & $T_{50}\left({ }^{\circ} \mathrm{C}\right)$ & Ref. \\
\hline \multicolumn{4}{|l|}{ Single metal oxide catalysts } \\
\hline $\mathrm{MnO}_{2}, \mathrm{Ag}_{2} \mathrm{O}, \mathrm{PdO}, \mathrm{CoO}, \mathrm{CuO}, \mathrm{ZnO}, \mathrm{Fe}_{2} \mathrm{O}_{3}$ & $<750$ ppm $\mathrm{HCHO}$ & - & {$[81,82]$} \\
\hline \multicolumn{4}{|l|}{$\mathrm{La}_{2} \mathrm{O}_{3}, \mathrm{~V}_{2} \mathrm{O}_{5}, \mathrm{TiO}_{2}, \mathrm{CeO}_{2}$ and $\mathrm{Mn}_{3} \mathrm{O}_{4}$} \\
\hline Cryptomelane & $100 \mathrm{ppm} \mathrm{HCHO,} 20 \mathrm{vol} \% \mathrm{O}_{2}, 50000 \mathrm{~h}^{-1} \mathrm{SV}$ & 90 & {$[83]$} \\
\hline Birnessite & & 95 & \\
\hline Ramsdellite & & 100 & \\
\hline $\mathrm{MnOOH}$ nanorods & & 115 & \\
\hline Pyrolusite & 400 ppm HCHO, 10 vol\% $\mathrm{O}_{2}, 18000 \mathrm{~mL} /(\mathrm{g} \cdot \mathrm{h}) \mathrm{SV}$ & 150 & {$[84]$} \\
\hline Cryptomelane & & 110 & \\
\hline Todorokite & & 140 & \multirow{4}{*}{ [69] } \\
\hline Cocoon-like $\mathrm{MnO}_{2}$ & \multirow{3}{*}{$460 \mathrm{ppm} \mathrm{HCHO,} 20000 \mathrm{~mL} /(\mathrm{g} \cdot \mathrm{h}) \mathrm{SV}$} & 130 & \\
\hline Urchin-like $\mathrm{MnO}_{2}$ & & 120 & \\
\hline Nest-like $\mathrm{MnO}_{2}$ & & 110 & \\
\hline Hollow $\mathrm{K}_{x} \mathrm{MnO}_{2}$ & \multirow[t]{2}{*}{$100 \mathrm{ppm} \mathrm{HCHO}, 20$ vol\% $\mathrm{O}_{2}, 50000 \mathrm{~h}^{-1} \mathrm{SV}$} & 50 & \multirow[t]{2}{*}{ [88] } \\
\hline Honeycomb $\mathrm{MnO}_{2}$ & & 70 & \\
\hline OMS-2 nanorods & \multirow{2}{*}{$0.01 \%$ HCHO, 20 vol\% O $2,24000 \mathrm{~mL} /(\mathrm{g} \cdot \mathrm{h}) \mathrm{SV}$} & 75 & \multirow[t]{2}{*}{ [89] } \\
\hline $\mathrm{MnO}_{x}$ & & 85 & \\
\hline OMS-2 & $500 \mathrm{ppm}$ HCHO, 10 vol\% $\mathrm{O}_{2}, 30000 \mathrm{~mL} /(\mathrm{g} \cdot \mathrm{h}) \mathrm{SV}$ & 110 & {$[80]$} \\
\hline OMS-2 nanoparticles & \multirow{2}{*}{$460 \mathrm{ppm}$ HCHO, 21 vol\% O2, $20000 \mathrm{~mL} /(\mathrm{g} \cdot \mathrm{h}) \mathrm{SV}$} & 90 & \multirow[t]{2}{*}{ [90] } \\
\hline OMS-2 nanorods & & $>100$ & \\
\hline Birnessite $\mathrm{MnO}_{2}$ & $460 \mathrm{ppm}$ HCHO, 21 vol\% $\mathrm{O}_{2}, 30000 \mathrm{~mL} /(\mathrm{g} \cdot \mathrm{h}) \mathrm{SV}$ & 80 & [91] \\
\hline $3 \mathrm{D}-\mathrm{Cr}_{2} \mathrm{O}_{3}$ & $500 \mathrm{ppm} \mathrm{HCHO}, 30000 \mathrm{~mL} /(\mathrm{g} \cdot \mathrm{h}) \mathrm{SV}$ & 92 & [92] \\
\hline $3 \mathrm{DOM} \mathrm{CeO}{ }_{2}$ & $0.06 \%$ HCHO, $66000 \mathrm{~mL} /(\mathrm{g} \cdot \mathrm{h}) \mathrm{SV}$ & 250 & [72] \\
\hline $3 \mathrm{D}-\mathrm{Co}_{3} \mathrm{O}_{4}$ & \multirow[t]{3}{*}{$400 \mathrm{ppm} \mathrm{HCHO}, 20$ vol\% $\mathrm{O}_{2}, 30000 \mathrm{~mL} /(\mathrm{g} \cdot \mathrm{h}) \mathrm{SV}$} & $<110$ & \multirow[t]{3}{*}[42]{} \\
\hline $2 \mathrm{D}-\mathrm{Co}_{3} \mathrm{O}_{4}$ & & $<130$ & \\
\hline $\mathrm{Co}_{3} \mathrm{O}_{4}$ nanopaticles & & $<210$ & \\
\hline $\mathrm{CeO}_{2}$ nanospheres & \multirow[t]{2}{*}{$810 \mathrm{ppm} \mathrm{HCHO}, 20$ vol\% $\mathrm{O}_{2}, 84000 \mathrm{~h}^{-1} \mathrm{SV}$} & 175 & \multirow[t]{2}{*}{ [79] } \\
\hline $\mathrm{CeO}_{2}$ bulk particles & & $>250$ & \\
\hline $3 \mathrm{D}-\mathrm{MnO}_{2}$ & \multirow{3}{*}{400 ppm HCHO, 20 vol\% O2, $30000 \mathrm{~mL} /(\mathrm{g} \cdot \mathrm{h}) \mathrm{SV}$} & $<100$ & \multirow[t]{3}{*}{ [94] } \\
\hline$\alpha-\mathrm{MnO}_{2}$ nanorods & & 100 & \\
\hline$\beta-\mathrm{MnO}_{2}$ nanorods & & $>140$ & \\
\hline \multicolumn{4}{|l|}{ Composite metal oxide catalysts } \\
\hline \multirow[t]{2}{*}{$\mathrm{MnO}_{x}-\mathrm{CeO}_{2}(\mathrm{Mn} / \mathrm{Ce}=1)$} & $580 \mathrm{ppm}$ HCHO, 20 vol $\% \mathrm{O}_{2}, 30000 \mathrm{~mL} /(\mathrm{g} \cdot \mathrm{h}) \mathrm{SV}$ & $<90$ & {$[62]$} \\
\hline & $580 \mathrm{ppm} \mathrm{HCHO}, 18$ vol\% $\mathrm{O}_{2}, 21000 \mathrm{~mL} /(\mathrm{g} \cdot \mathrm{h}) \mathrm{SV}$ & & [95] \\
\hline CeMn10 & 580 ppm $\mathrm{HCHO}, 20$ vol\% $\mathrm{O}_{2}$ & 150 & [96] \\
\hline CeMn30 & & 125 & \\
\hline CeMn50 & & 100 & \\
\hline CeMn80 & & 80 & \\
\hline $\mathrm{MnO}_{x}$ & & 72 & \\
\hline $\mathrm{CeO}_{2}$ & & 225 & \\
\hline $\mathrm{MnO}_{x}-\mathrm{SnO}_{2}$ & $400 \mathrm{ppm} \mathrm{HCHO}, 10 \mathrm{vol} \% \mathrm{O}_{2}, 30000 \mathrm{~mL} /(\mathrm{g} \cdot \mathrm{h}) \mathrm{SV}$ & 150 & [97] \\
\hline $\mathrm{CuO} / \mathrm{MnO}_{2}$ & $0.18-1.3 \mathrm{ppm}$ HCHO, $100000 \mathrm{~h}^{-1} \mathrm{SV}$ & $<120$ & [98] \\
\hline $\mathrm{Co}(\mathrm{N}) / \mathrm{Zr}$ & $150 \mathrm{ppm} \mathrm{HCHO}, 20$ vol\% $\mathrm{O}_{2}, 30000 \mathrm{~mL} /(\mathrm{g} \cdot \mathrm{h}) \mathrm{SV}$ & 170 & [99] \\
\hline Co-CD $0.1 / \mathrm{Zr}$ & & 155 & \\
\hline Mesoporous Co-Mn & $80 \mathrm{ppm} \mathrm{HCHO}, 36000 \mathrm{~h}^{-1} \mathrm{SV}, 50 \%$ relative humidity & - & {$[100]$} \\
\hline Mesoporous $\mathrm{Co}_{3} \mathrm{O}_{4}-\mathrm{CeO}_{2}$ & $200 \mathrm{ppm} \mathrm{HCHO}, 22 \mathrm{vol} \% \mathrm{O}_{2}, 55000 \mathrm{~h}^{-1} \mathrm{SV}$ & - & {$[75]$} \\
\hline
\end{tabular}


catalysts consisting of $\mathrm{Ag}$ and $\mathrm{Au}$ loaded on metal oxide supports with special morphologies. Such catalysts, e.g., mesoporous 3DOM Au/CeO $2-\mathrm{Co}_{3} \mathrm{O}_{4}$ [74], 2D $\mathrm{Au} / \mathrm{Co}_{3} \mathrm{O}_{4}-\mathrm{CeO}_{2}, 2 \mathrm{D}$ $\mathrm{Au} / \mathrm{Co}_{3} \mathrm{O}_{4}$ [75], and 3D $\mathrm{K}-\mathrm{Ag} / \mathrm{Co}_{3} \mathrm{O}_{4}$ [78], all have excellent catalytic activities in $\mathrm{HCHO}$ oxidation at room temperature $\left(T_{50}=\right.$ room temperature) and have good potential applications. The interactions between the noble metal and the support, dispersion, particle size, low-temperature reducibility, mobility and activation of active oxygen species, and redox cycles of highand low-valence states of metal ions are responsible for the excellent catalytic activities in HCHO oxidation. Experimental results have shown that $\mathrm{Au}$ and $\mathrm{Ag}$, which are cheaper than $\mathrm{Pt}$ and Pd, can provide sufficient active sites for HCHO oxidation (Table 1). Catalysts with $\mathrm{Au}$ and $\mathrm{Ag}$ on supports with special morphologies, especially porous structures, are promising for HCHO removal at room temperature and may become substitutes for Pt catalysts.

\section{Transition-metal oxide catalytic systems}

Precious-metal catalysts have excellent low-temperature catalytic activities in $\mathrm{HCHO}$ oxidation, but their industrial use is restricted because of their high costs. Precious-metal catalysts have poor thermal stabilities at $500-900^{\circ} \mathrm{C}$. These catalysts are easily sintered, resulting in decreased surface area, which decreases their catalytic activities. Transition-metal oxides are cheap and plentiful, and transition-metal oxide catalysts have potential applications in VOC removal. Transition-metal oxide catalysts with good thermal stabilities have therefore attracted much attention. Transition-metal oxide catalysts with good activities $\left(T_{100} \leq 140{ }^{\circ} \mathrm{C}\right)$ in HCHO oxidation mainly contain Mn, $\mathrm{Co}$, and $\mathrm{Cr}$. Other metal elements such as $\mathrm{Ce}, \mathrm{Sn}, \mathrm{Cu}$, and $\mathrm{Zr}$ can be doped into $\mathrm{MnO}_{x}$ and $\mathrm{Co}_{3} \mathrm{O}_{4}$ to prepare composite metal oxides if a single metal oxide does not give a good catalytic performance. In addition, a single rare-earth oxide, i.e., $\mathrm{CeO}_{2}$, has been used in the catalytic oxidation of HCHO. Table 2 gives an overview of the catalytic activities of transition-metal oxides in HCHO oxidation.

\subsection{Single metal oxide catalysts}

In 2001, Sekine et al. [81] developed a cardboard-like air purification material composed mainly of activated carbon particles and $\mathrm{MnO}_{x}$. The material was tested by many families in Japan. This material reduced indoor HCHO concentrations from 0.21 to $0.04 \mathrm{ppm}$, and desorbed HCHO molecules from indoor building materials. In 2002, Sekine [82] also reported catalytic $\mathrm{HCHO}$ oxidations using various metal oxides such as $\mathrm{Ag}_{2} \mathrm{O}, \mathrm{PdO}, \mathrm{CoO}, \mathrm{CuO}, \mathrm{ZnO}, \mathrm{Fe}_{2} \mathrm{O}_{3}, \mathrm{La}_{2} \mathrm{O}_{3}, \mathrm{~V}_{2} \mathrm{O}_{5}, \mathrm{MnO}_{2}, \mathrm{TiO}_{2}, \mathrm{CeO}_{2}$, and $\mathrm{Mn}_{3} \mathrm{O}_{4}$. Apart from those with $\mathrm{La}_{2} \mathrm{O}_{3}, \mathrm{ZnO}$, and $\mathrm{CuO}, \mathrm{Fe}_{2} \mathrm{O}_{3}$, and $\mathrm{V}_{2} \mathrm{O}_{5}$, the $\mathrm{HCHO}$ conversion rates of these oxides were above $50 \% \cdot \mathrm{MnO}_{2}$ showed the best catalytic activity. The catalytic activities of two types of $\mathrm{MnO}_{2}$ were tested. The catalytic performance of the $\mathrm{MnO}_{2}$ sample with a higher specific surface area was better, because a higher specific surface area is conducive to the adsorption and oxidation of gas-phase components. The $\mathrm{MnO}_{2}$ catalyst contains multi-holes, therefore oxy- gen molecules can easily spread to the active sites on the surface, giving complete $\mathrm{HCHO}$ conversion at $100^{\circ} \mathrm{C}$.

Since 2002, most research has focused on $\mathrm{MnO}_{2}$ catalysts for $\mathrm{HCHO}$ oxidation because its catalytic activity is better than those of other oxides such as $\mathrm{CuO}, \mathrm{Fe}_{2} \mathrm{O}_{3}, \mathrm{La}_{2} \mathrm{O}_{3}, \mathrm{~V}_{2} \mathrm{O}_{5}, \mathrm{TiO}_{2}$, and $\mathrm{CeO}_{2} . \mathrm{MnO}_{2}$ has various morphologies, namely $\alpha, \beta, \gamma$ and $\delta$ types. Zhou et al. [83] used a hydrothermal method to prepare $\mathrm{MnO}_{2}$ samples consisting of cryptomelane, birnessite, and ramsdellite, and monoclinic crystalline $\mathrm{MnOOH}$ nanorods. Of these, cryptomelane $\mathrm{MnO}_{2}$ has the best catalytic properties. Chen et al. [84] prepared pyrolusite, cryptomelane, and todorokite manganese oxides with different channel structures. The catalytic activity of cryptomelane $\mathrm{MnO}_{2}$ is better than those of the others (Fig. 7). The effect of pore channels in HCHO oxidation is stronger than those of crystallinity, specific surface area, reducibility, and Mn oxidation state. Cryptomelane has the best catalytic activity mainly because the HCHO molecules and pore channels are of similar size. It has been reported in Ref. $[83,84]$ that the crystalline structure of a catalyst determines its catalytic activity.

Experimental and theoretical results have shown that the catalytic oxidation activity is affected by factors such as structure, specific surface area, active oxygen species, and active phase [85-87]. Most metal oxides synthesized by traditional precipitation methods have relatively small specific surface areas, fewer exposed active sites or oxygen species, and poor low-temperature reducibility. These limitations are a drawback in catalytic oxidation of HCHO. Properties such as a large specific surface area, good low-temperature reducibility, and large number of active sites enhance the catalytic ability. Materials containing the same components, but with different morphologies and structures, have different functions. Researchers are now trying to change the structures and morphologies of metal oxides to control the factors that influence their catalytic activities.

$\mathrm{MnO}_{2}$ synthesized with various morphologies such as rods, spheres, particles, and porous have enhanced catalytic properties. $\mathrm{Yu}$ et al. [69] prepared $\mathrm{MnO}_{2}$ materials with cocoon, sea-urchin, and nest morphologies (Fig. 8). Nest-like $\mathrm{MnO}_{2}$ has the best HCHO oxidation activity because of its hole structure, which is beneficial for the adsorption and transformation of HCHO. The $\mathrm{MnO}_{2}$ nests have diameters in the range $1-3 \mu \mathrm{m}$, and consist of nanorods of width 10-50 nm and length $0.2-1.5$ $\mu \mathrm{m}$. Chen et al. [88] reported that hollow $\mathrm{K}_{x} \mathrm{MnO}_{2}$ nanospheres

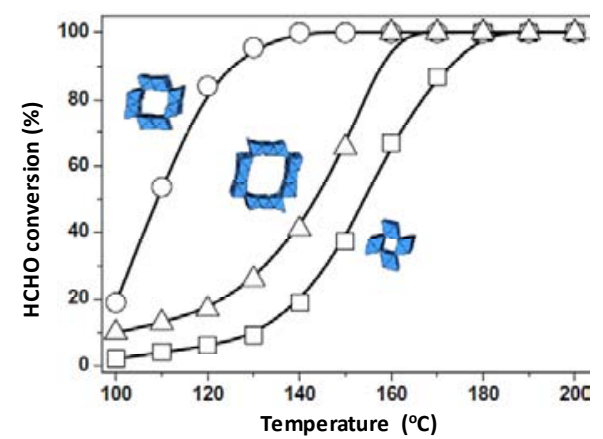

Fig. 7. Complete oxidation of HCHO on pyrolusite, cryptomelane, and todorokite manganese oxides [84]. 

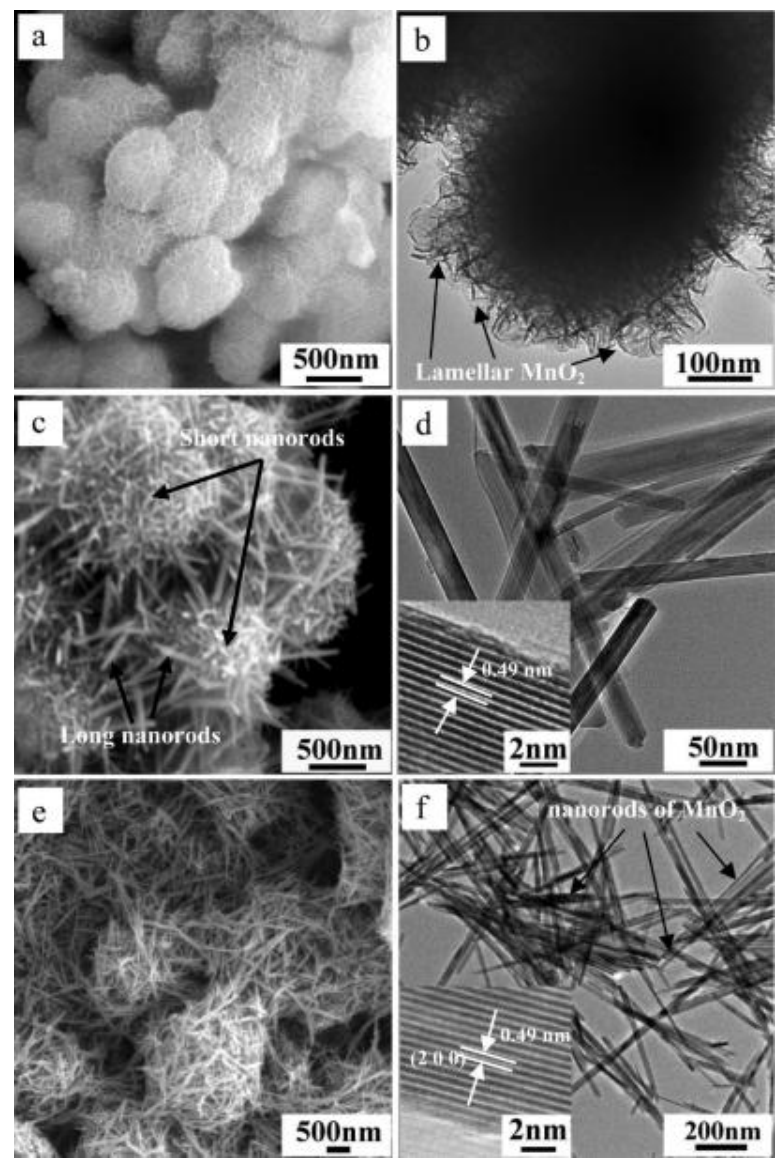

Fig. 8. SEM (a, c, e) and TEM (b, d, f) images of three $\mathrm{MnO}_{2}$ nanostructures: (a, b) cocoon-like $\mathrm{MnO}_{2}$, (c, d) sea-urchin-like $\mathrm{MnO}_{2}$, (e, f) nest-likeMnO 2 [69].

gave good catalytic performance in low-temperature $\mathrm{HCHO}$ oxidation, with complete conversion at $80^{\circ} \mathrm{C}$. The catalytic activity of this material is superior to those of OMS-2, traditional $\mathrm{MnO}_{x}$ powder, and $\mathrm{Mn}-\mathrm{Pd} / \mathrm{Al}_{2} \mathrm{O}_{3}$. The structure and $\mathrm{HCHO}$ conversion data for the catalyst are shown in Fig. 9. Tang et al. [89] reported that the catalytic performance of OMS-2 nanorods with a molecular sieve structure consisting of octahedral $\mathrm{Mn}$ was better than that of traditional $\mathrm{MnO}_{x}$. Tian et al. [90] prepared K-OMS-2 nanoparticles with an octahedral Mn structure; its HCHO oxidation activity was superior to that of OMS-2 nanorods. This group [91] also prepared $\mathrm{MnO}_{x}$ catalysts with a birnessite structure; they had excellent catalytic activities in
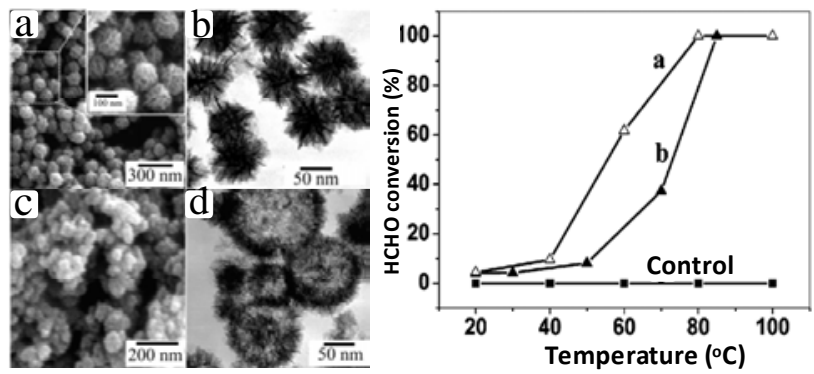

Fig. 9. SEM and TEM images of honeycomb $\mathrm{K}_{x} \mathrm{MnO}_{2}$ nanospheres (a,b) and hollow $\mathrm{K}_{x} \mathrm{MnO}_{2}$ nanospheres (c,d); HCHO conversions over hollow $\mathrm{K}_{x} \mathrm{MnO}_{2}$ nanospheres (a) and honeycomb $\mathrm{K}_{x} \mathrm{MnO}_{2}$ nanospheres (b) [88].
HCHO oxidation because of the special topography, large surface area, and good surface reducibility.

Morphological changes can improve the factors that influence catalytic activity, such as the specific surface area, low-temperature reducibility, and active phase. Research has not been confined to $\mathrm{MnO}_{2}$ materials with various structures and morphologies. Other transition-metal oxides $\left(\mathrm{Cr}_{2} \mathrm{O}_{3}\right.$ and $\left.\mathrm{Co}_{3} \mathrm{O}_{4}\right)$ and a rare-earth oxide $\left(\mathrm{CeO}_{2}\right)$ have been studied. Xia et al. [92] reported the use of 3D ordered mesoporous $\mathrm{Cr}_{2} \mathrm{O}_{3}$ in catalytic oxidation of HCHO. The TEM images in Fig. 10 show the mesoporous structure of the catalyst. Mesoporous $\mathrm{Cr}_{2} \mathrm{O}_{3}$ calcined at $400{ }^{\circ} \mathrm{C}$ has the best $\mathrm{HCHO}$ oxidation activity, and complete $\mathrm{HCHO}$ conversion is achieved at $130{ }^{\circ} \mathrm{C}$ with $500 \mathrm{ppm}$ $\mathrm{HCHO}$ and a GHSV of $30000 \mathrm{~mL} /(\mathrm{g} \cdot \mathrm{h}$ ) (Fig. 10). The activation energy is $45.6 \mathrm{~kJ} / \mathrm{mol}$. The specific surface area of mesoporous $\mathrm{Cr}_{2} \mathrm{O}_{3}\left(69-124 \mathrm{~m}^{2} / \mathrm{g}\right.$ ) is larger than that of traditional bulk $\mathrm{Cr}_{2} \mathrm{O}_{3}$; it also has better low-temperature reducibility, which enhances its catalytic properties. The catalytic activity is also related to the catalyst preparation process and the template quality. Zhang et al. [72] reported a $3 \mathrm{DOM} \mathrm{CeO}_{2}$ catalyst with a controllable pore size. The catalytic activity in HCHO oxidation of a catalyst with a pore diameter of $80 \mathrm{~nm}$ is better than that of one with a pore diameter of $130 \mathrm{~nm}$; it has a larger surface area and can completely convert $\mathrm{HCHO}$ to $\mathrm{CO}_{2}$ and $\mathrm{H}_{2} \mathrm{O}$ at $355^{\circ} \mathrm{C}$.

Our group used SBA-15 and KIT- 6 as hard templates to prepare $2 \mathrm{D} \mathrm{Co}_{3} \mathrm{O}_{4}$ and $3 \mathrm{D} \mathrm{Co}_{3} \mathrm{O}_{4}$ catalysts [42]. The materials have the structural characteristics of their templates, and contain 2D hexagonal (p6mm) pore channel structures and 3D symmetrical cubic (ia3d) structures, respectively. These materials all have the crystalline cobalt oxide spinel structure. The $3 \mathrm{D} \mathrm{Co}_{3} \mathrm{O}_{4}$ catalyst gave $100 \% \mathrm{HCHO}$ conversion at $130{ }^{\circ} \mathrm{C}$ and a

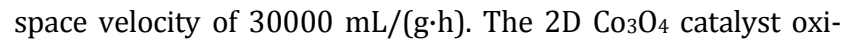
dized $\mathrm{HCHO}$ completely at $140{ }^{\circ} \mathrm{C}$ under the same space velocity conditions (Fig. 11). The difference between the activities of these catalysts arises from the channel structure of the mesoporous $\mathrm{Co}_{3} \mathrm{O}_{4}$ prepared using the hard template method; it has a high specific surface area and a large number of surface-active species, enabling reactants to diffuse and undergo surface reactions. The Brunauer-Emmett-Teller specific surface areas of $2 \mathrm{D} \mathrm{Co}_{3} \mathrm{O}_{4}$ and $3 \mathrm{D} \mathrm{Co}_{3} \mathrm{O}_{4}$ are 43.3 and $85.9 \mathrm{~m}^{2} / \mathrm{g}$, respectively; these values are much larger than that of traditional nano- $\mathrm{Co}_{3} \mathrm{O}_{4}\left(28.1 \mathrm{~m}^{2} / \mathrm{g}\right)$. A catalyst with a larger specific surface area exposes more active facets during oxidation. TEM images show that the active faces of $3 \mathrm{D} \mathrm{Co}_{3} \mathrm{O}_{4}$ are (220) crystal
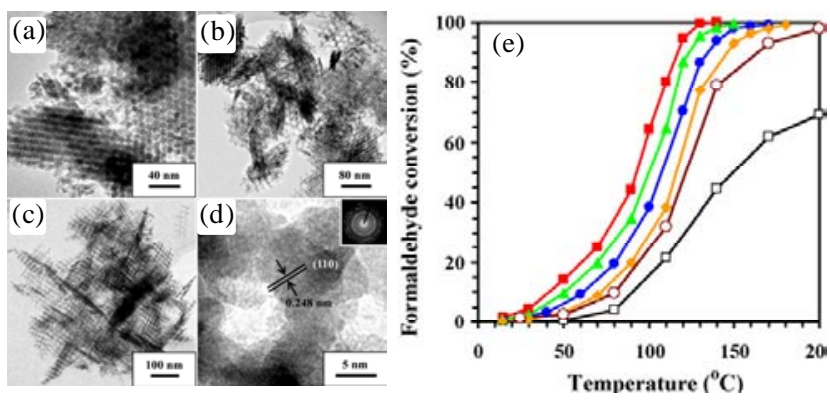

Fig. 10. TEM images (a-d) and HCHO conversions (e) over $3 \mathrm{D}^{\mathrm{Cr}_{2} \mathrm{O}_{3}}$ catalyst [92]. 

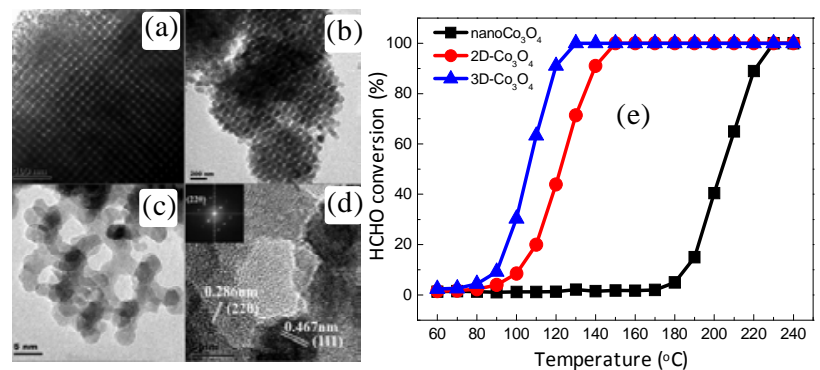

Fig. 11. TEM images (a-d) and $\mathrm{HCHO}$ conversions (e) over $3 \mathrm{D} \mathrm{Co}_{3} \mathrm{O}_{4}$ catalyst [42].

planes (Fig. 11), which mainly consist of abundant $\mathrm{Co}^{3+}$ ions, which provide sufficient active sites for oxidation. Large numbers of $\mathrm{Co}^{3+}$ ions are exposed on its surface, further enhancing the catalytic ability. X-ray photoelectron spectroscopy shows that greater quantities of $\mathrm{Co}^{3+}$ ions are present on the surface of $3 \mathrm{D} \mathrm{Co}_{3} \mathrm{O}_{4}$ than on that of $2 \mathrm{D} \mathrm{Co}_{3} \mathrm{O}_{4}$. A larger number of $\mathrm{Co}^{3+}$ species can increase the number of anionic defects, and this promotes adsorption and activation of oxygen in the gas phase. Oxygen temperature-programmed desorption shows that mesoporous $\mathrm{Co}_{3} \mathrm{O}_{4}$, particularly 3D $\mathrm{Co}_{3} \mathrm{O}_{4}$, has a large number of surface-active oxygen species, which are easily stripped off and quickly filled by gas-phase oxygen. This improves the oxidation capacity. Larger surface areas, more abundant surface-active oxygen species, and a larger amount $\mathrm{Co}^{3+}$ active species are responsible for the improved oxidation activity. Our group also prepared $\mathrm{CeO}_{2}$ nanospheres [79]. The catalytic activity of $\mathrm{CeO}_{2}$ nanospheres in $\mathrm{HCHO}$ oxidation is better than that of traditional bulk $\mathrm{CeO}_{2}$ nanoparticles (Fig. 6). The $\mathrm{HCHO}$ conversion rate with $\mathrm{CeO}_{2}$ nanospheres is $85 \%$ at $200{ }^{\circ} \mathrm{C}$, whereas that of bulk $\mathrm{CeO}_{2}$ nanoparticles is only $40 \%$. This is because $\mathrm{CeO}_{2}$ nanospheres have a larger specific surface area $\left(148.6 \mathrm{~m}^{2} / \mathrm{g}\right)$ than bulk $\mathrm{CeO}_{2}\left(57.8 \mathrm{~m}^{2} / \mathrm{g}\right)$. A morphological change can increase the specific surface area or affect other factors that influence the catalytic activity in $\mathrm{HCHO}$ oxidation, and can therefore enhance the oxidation performance. Our group $[93,94]$ reported that the catalytic activity of a 3D ordered mesoporous $\mathrm{MnO}_{2}$ catalyst $\left(T_{100}<140{ }^{\circ} \mathrm{C}\right)$ in $\mathrm{HCHO}$ and ethanol oxidation is better than that of $\mathrm{MnO}_{2}$ nanorods because it contains more $\mathrm{Mn}^{4+}$ ions as the active phase and has a higher specific surface area.

Table 2 shows that single metal oxide catalysts such as $\mathrm{MnO}_{2}$ nanorods, cryptomelane nanospheres, and mesorporous $\mathrm{MnO}_{2}, \mathrm{Co}_{3} \mathrm{O}_{4}$, and $\mathrm{Cr}_{2} \mathrm{O}_{3}$ have good catalytic activities in $\mathrm{HCHO}$ oxidation, and their $T_{50}$ and $T_{100} \mathrm{HCHO}$ conversions are less than or equal to 110 and $140{ }^{\circ} \mathrm{C}$, respectively. Their catalytic activities are superior to those of traditional metal oxide catalysts synthesized using precipitation methods. This is because these catalysts have special morphologies and structures and high surface areas, which promote $\mathrm{HCHO}$ activation on the catalyst surface. Morphological changes can increase the surface area and, more importantly, increase the low-temperature reducibility, and numbers of active cations and surface-active oxygen species, and therefore increase the oxidation ability of the catalyst. Single metal oxide catalysts with special morphol- ogies have a range of potential applications because they are cheap and give good catalytic performances.

\subsection{Composite metal oxide catalysts}

The development of transition-metal oxide catalysts that can completely convert $\mathrm{HCHO}$ at room temperature is desirable. Some single metal oxides cannot convert $\mathrm{HCHO}$ at low temperatures; other elements such as $\mathrm{Ce}, \mathrm{Sn}, \mathrm{Zr}$, and $\mathrm{Cu}$ have been added to manganese and cobalt oxides to prepare $\mathrm{Mn}$ and Co-based catalysts.

Tang et al. [62] used a coprecipitation method to prepare a $\mathrm{MnO}_{x}-\mathrm{CeO}_{2}$ mixed oxide, and investigated the effect of the $\mathrm{Mn} /(\mathrm{Mn}+\mathrm{Ce})$ molar ratio on its catalytic performance in $\mathrm{HCHO}$ oxidation. The best catalytic activity was obtained when the $\mathrm{Mn} / \mathrm{Ce}$ mole ratio was 1:1. HCHO conversion of $90 \%$ was achieved at $90^{\circ} \mathrm{C}$ with a $580 \mathrm{ppm}$ feed concentration and space velocity of $30000 \mathrm{~mL} /(\mathrm{g} \cdot \mathrm{h})$. Formation of a solid solution and improved reducibility are responsible for the good catalytic performance. Tang et al. [95] also reported $\mathrm{Mn}-\mathrm{Ce}$ catalysts. A $\mathrm{MnO}_{x}-\mathrm{CeO}_{2}$ sample prepared using a modified coprecipitation method completely converted $\mathrm{HCHO}$ at $100{ }^{\circ} \mathrm{C}$ at $580 \mathrm{ppm}$ HCHO and a GHSV of $21000 \mathrm{~mL} /$ (g.h) (Fig. 12). The large number of $\mathrm{Mn}^{4+}$ ions and surface lattice oxygen species are responsible for the excellent catalytic activity in $\mathrm{HCHO}$ oxidation. Liu et al. [96] also prepared a $\mathrm{MnO}_{x}-\mathrm{CeO}_{2}$ catalyst. The average oxidation state of Mn species on the catalyst surface was higher than that of pure $\mathrm{MnO}_{\mathrm{x}}$. An improved catalytic performance in $\mathrm{HCHO}$ oxidation was achieved because of activation of surface lattice oxygen species. Wen et al. [97] reported the preparation of $\mathrm{MnO}_{x}-\mathrm{SnO}_{2}$ catalysts using a coprecipitation method. These gave good catalytic performances in $\mathrm{HCHO}$ oxidation because of the presence of high-oxidation-state Mn species and the formation of a Mn-Sn solid solution. Pei et al. [98] reported the performance and kinetics of a $\mathrm{CuO} / \mathrm{MnO}_{2}$ catalyst for indoor $\mathrm{HCHO}$ removal. The experimental data for $\mathrm{HCHO}$ oxidation over the $\mathrm{CuO} / \mathrm{MnO}_{2}$ catalyst fitted the traditional Langmuir-Hinshelwood model.

Bai et al. [99] used cyclodextrin (CD) to prepare a $\mathrm{Co}_{3} \mathrm{O}_{4} / \mathrm{Zr}$ catalyst. The catalytic performance of the material containing $\mathrm{CD}$ and Co in a molar ratio of 0.1:1 was better than that of a catalyst directly prepared from cobalt nitrate; this is attributed

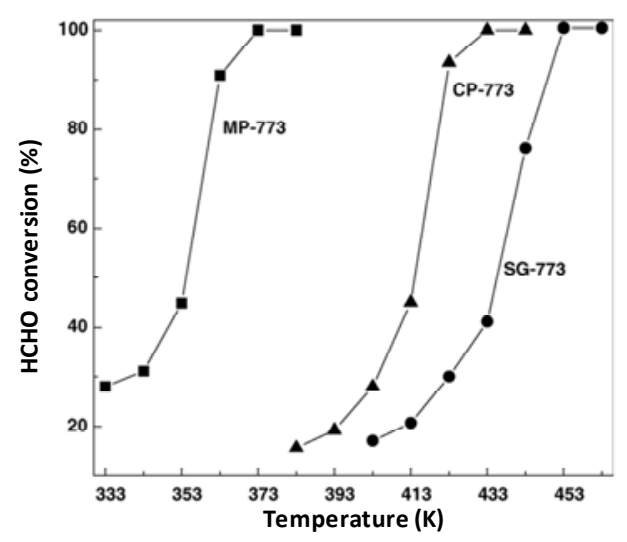

Fig. 12. $\mathrm{HCHO}$ conversions over various $\mathrm{MnO}_{x}-\mathrm{CeO}_{2}$ catalysts [95]. 
to stronger interactions between Co and the carrier and better reducibility. Complete $\mathrm{HCHO}$ conversion was achieved over the Co-CD $0.1 / \mathrm{Zr}$ catalyst at $180{ }^{\circ} \mathrm{C}$ with $150 \mathrm{ppm} \mathrm{HCHO}$ and a GHSV of $30000 \mathrm{~mL} /(\mathrm{g} \cdot \mathrm{h})$ (Fig. 13). Wang et al. [100] prepared a 3D ordered mesoporous Co-Mn mixed oxide. This catalyst removed HCHO efficiently because of its large specific surface area and specific pore structure.

Table 2 shows that $\mathrm{MnO}_{x}-\mathrm{CeO}_{2}$ composite metal oxide catalysts $[62,95,96]$ have good catalytic activities $\left(T_{50}<100{ }^{\circ} \mathrm{C}\right)$. This is because strong interactions between $\mathrm{MnO}_{x}$ and $\mathrm{CeO}_{2}$ change the number of surface-active oxygen species and the active phase. Ma et al. [75] prepared 2D ordered mesoporous $\mathrm{Co}_{3} \mathrm{O}_{4}-\mathrm{CeO}_{2}$. Under the same conditions, the HCHO conversion $(20.3 \%)$ over $2 \mathrm{D} \mathrm{Co}_{3} \mathrm{O}_{4}$ was higher than that $(13.2 \%)$ over $2 \mathrm{D}$ $\mathrm{Co}_{3} \mathrm{O}_{4}-\mathrm{CeO}_{2}$. This indicates that the addition $\mathrm{Ce}$ does not increase the catalytic activity, probably because a solid solution is not formed. Few composite metal oxide catalysts have been reported; therefore, syntheses of composite metal oxide catalysts with special morphologies for lower-temperature catalytic activity need to be developed.

\section{Factors affecting HCHO oxidation activity}

The catalytic activities of metal and transition-metal oxide catalytic systems in $\mathrm{HCHO}$ oxidation are affected by factors such as the preparation method, morphology and structure, specific surface area, active sites, low-temperature reducibility, and surface active oxygen species; these effects are inter-related. In addition, HCHO conversion by catalysts is influenced by experimental parameters such as the water vapor content, initial HCHO concentration, and space velocity.

\subsection{Effect of preparation method}

Catalysts or supports with different morphologies or higher surface areas can be obtained by using different preparation methods. The catalytic activity in HCHO oxidation varies de-

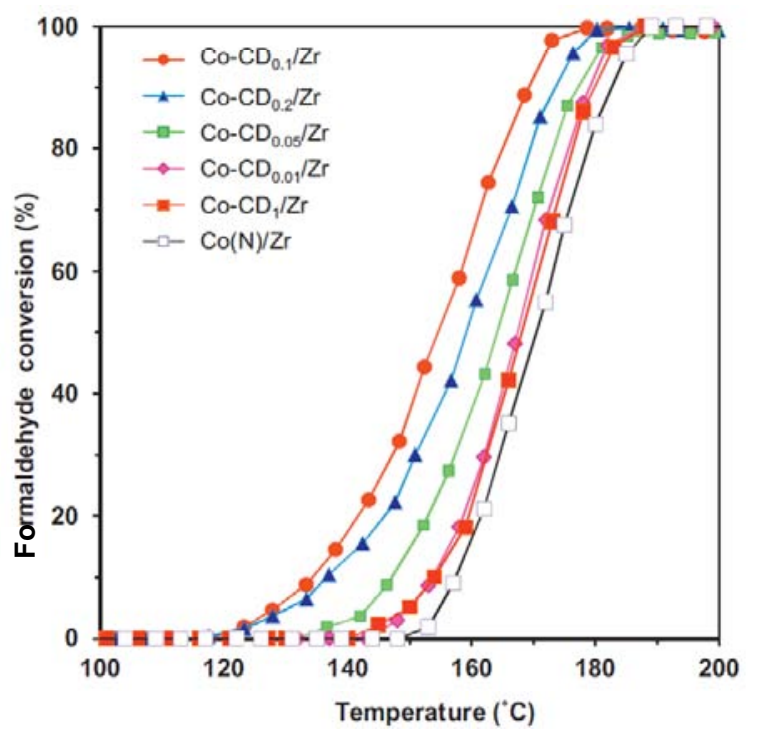

Fig. 13. $\mathrm{HCHO}$ conversions over various $\mathrm{Co}_{-} \mathrm{CD}_{x} / \mathrm{Zr}$ catalysts [99]. pending on important factors such as active sites, surface-active oxygen species, and low-temperature reducibility. Changing the method used to prepare catalysts or supports is therefore an efficient way to obtain excellent catalytic activities for HCHO oxidation.

Zhou et al. [83] used $\mathrm{KMnO}_{4}$ and oleic acid for the hydrothermal synthesis of $\mathrm{MnO}_{2}$ samples with different crystalline structures (cryptomelane, birnessite, ramsdellite, and monoclinic crystals) and morphologies (nanosheets, nanospheres, and nanorods). They examined the effects of hydrothermal temperature, $\mathrm{pH}$, and anion $\left(\mathrm{PO}_{4}{ }^{3-}, \mathrm{SO}_{4}{ }^{2-}\right.$ and $\left.\mathrm{NO}_{3}{ }^{-}\right)$on the morphology and structure of $\mathrm{MnO}_{2}$. The preparation method is shown in Fig. 14. The morphologies and structures of samples prepared hydrothermally at 80,120 , and $180{ }^{\circ} \mathrm{C}$ are $\delta-\mathrm{MnO}_{2}$ nanosheets, flower-like $\delta$ - $\mathrm{MnO}_{2}$, and $\gamma$ - $\mathrm{MnOOH}$ nanorods, respectively. The $\mathrm{pH}$ affects the size of cryptomelane $\alpha-\mathrm{MnO}_{2}$ nanorods. The samples prepared using $\mathrm{PO}_{4}^{3-}, \mathrm{SO}_{4}{ }^{2-}$, and $\mathrm{NO}_{3}-$ anions are flower-like $\delta-\mathrm{MnO}_{2}, \alpha-\mathrm{MnO}_{2}$ nanorods, and ramsdellite $\mathrm{MnO}_{2}$, respectively. The results show that the crystalline structure of the catalyst significantly affects HCHO oxidation. Below $120{ }^{\circ} \mathrm{C}$, the order of the catalytic activities in $\mathrm{HCHO}$ oxidation is cryptomelane $\mathrm{MnO}_{2}>$ birnessite $\mathrm{MnO}_{2}>$ ramsdellite $\mathrm{MnO}_{2}>$ monoclinic $\mathrm{MnOOH}$. The high activity of cryptomelane $\mathrm{MnO}_{2}$ is attributed to the specific tunnel size of $0.46 \times 0.46 \mathrm{~nm}^{2}$, and large numbers of defects and surface hydroxyl groups. Tang et al. [95] prepared $\mathrm{MnO}_{x}-\mathrm{CeO}_{2}$ catalysts using sol-gel, coprecipitation, and modified coprecipitation methods. The $\mathrm{MnO}_{x}-\mathrm{CeO}_{2}$ sample prepared using the modified coprecipitation method gives the best catalytic performance in HCHO oxidation because it has more $\mathrm{Mn}^{4+}$ ions and surface lattice oxygen species. The formation of a solid-solution crystalline structure and improved reducibility also contribute to excellent oxidation activity. The $\mathrm{Na}-\mathrm{Pt} / \mathrm{TiO}_{2}$ catalyst prepared by Zhang et al. [46] has the best activity in HCHO oxidation because of the addition of $\mathrm{Na}^{+}$ions as auxiliaries during prepara-

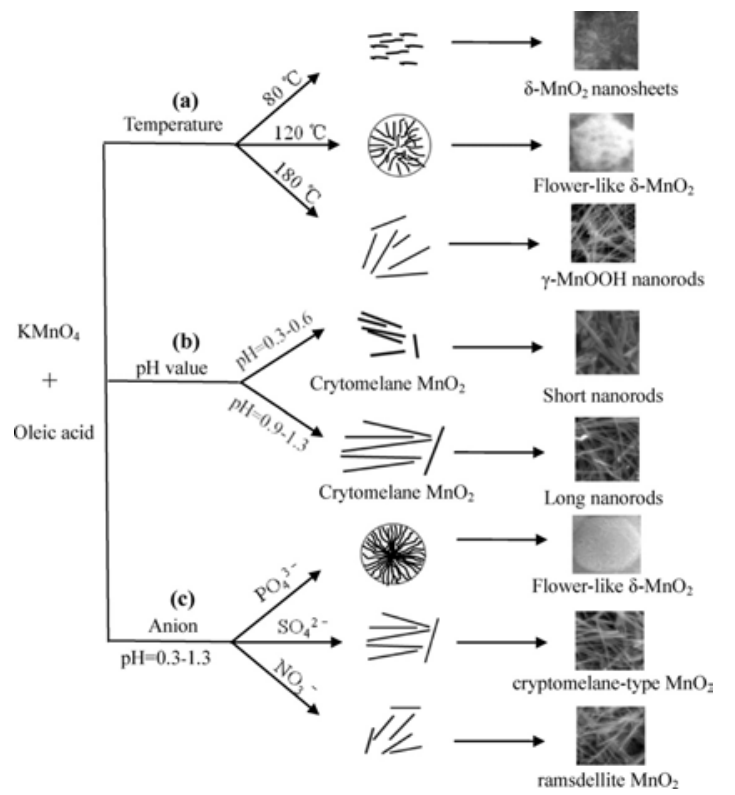

Fig. 14. Schematic diagram of growth of different manganese oxide nanostructures under various conditions [83]. 
tion. The addition of auxiliaries clearly increases the catalytic ability of $\mathrm{Pt} / \mathrm{TiO}_{2}$. $\mathrm{HCHO}$ at $600 \mathrm{ppm}$ can be completely converted to $\mathrm{CO}_{2}$ and $\mathrm{H}_{2} \mathrm{O}$ at room temperature and a GHSV of $300000 \mathrm{~h}^{-1}$ because of the large number of surface hydroxyl groups as surface-active oxygen species and better low-temperature reducibility. Our group [42] prepared mesoporous $\mathrm{Co}_{3} \mathrm{O}_{4}$ and bulk $\mathrm{Co}_{3} \mathrm{O}_{4}$ nanoparticles using hard template and precipitation methods, respectively. Mesoporous $\mathrm{Co}_{3} \mathrm{O}_{4}$ has better catalytic activity in $\mathrm{HCHO}$ oxidation, because the preparation method produces mesoporous $\mathrm{Co}_{3} \mathrm{O}_{4}$ with a special structure and morphology and an increased surface area; this enhances the active phase and low-temperature reducibility.

Table 1 and 2 confirm that the preparation method affects the catalytic activities of many catalysts. Transition-metal oxides with special morphologies and Ag or Au catalysts with such oxides as supports have promising low-temperature catalytic activities in HCHO oxidation because of the preparation methods used. However, catalyst preparation involves various factors such as choice of precipitant, the deposition rate, hydrothermal time and temperature, $\mathrm{pH}$, template type, calcination temperature, auxiliaries, and choice of active components and supports. Much effort has been expended on the preparation of catalytic materials, but complete elimination of $\mathrm{HCHO}$ at room temperature has not yet been achieved. The experimental procedures for synthesizing materials is difficult and complex. One of the main aims in catalysis research is therefore the preparation of highly efficient catalysts using different methods.

\subsection{Effects of morphology and structure}

The morphologies and structures of catalysts depend on the preparation methods. Different morphologies and structure result in different surface areas, active phases or facets, reducibilities, and active oxygen species, and these affect the catalytic activities.

Our group [93,94] prepared 3D ordered mesoporous $\mathrm{MnO}_{2}$, and $\alpha$ - and $\beta-\mathrm{MnO}_{2}$ nanorod catalysts using hard template and hydrothermal methods, respectively. 3D $\mathrm{MnO}_{2}$ consists of a $\beta-\mathrm{MnO}_{2}$ crystalline phase corresponding to pyrolusite with a rutile structure. It has (211) and (332) low-angle diffraction peaks, which are characteristic of 3D ordered mesoporous structures with cubic symmetry (ia3d). The unit cell parameter of $3 \mathrm{D} \mathrm{MnO}_{2}$, calculated from the (211) diffraction, is $20.85 \mathrm{~nm}$, and the unit cell parameter of the KIT- 6 template is $21.63 \mathrm{~nm}$. The two numbers are nearly equal, which confirms that 3D $\mathrm{MnO}_{2}$ successfully replicates the $3 \mathrm{D}$ mesoporous structure of the KIT- 6 template. Fig. 15 shows the ordered cubic (ia3d) mesoporous structure. The lattice dimension $(19.66 \mathrm{~nm})$, which was determined using TEM, matches the value calculated from the $d_{211}$ spacing in the X-ray diffraction pattern. The electron diffraction pattern shows that $3 \mathrm{D} \mathrm{MnO}_{2}$ has a disordered polycrystalline wall. 3D $\mathrm{MnO}_{2}$ also exposes the (110) and (101) crystal planes. $\alpha$ - and $\beta-\mathrm{MnO}_{2}$ nanorods are non-porous materials (Fig. 15) with low surface areas and cryptomelane and pyrolusite, structures, respectively. $3 \mathrm{D} \mathrm{MnO}_{2}$ gives a better

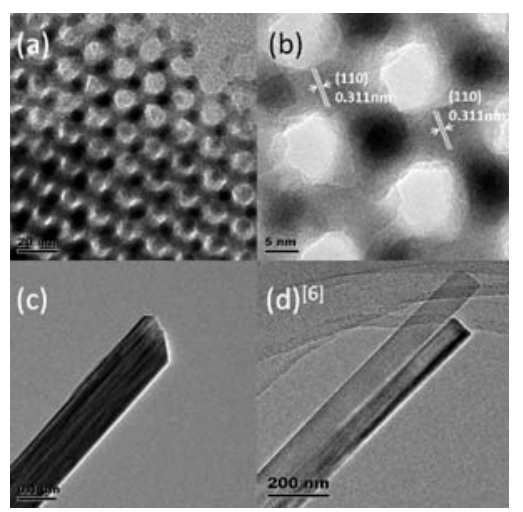

Fig. 15. TEM images of $3 \mathrm{D} \mathrm{MnO}_{2}(\mathrm{a}, \mathrm{b}), \mathrm{\alpha}-\mathrm{MnO}_{2}$ nanorods (c), and $\beta-\mathrm{MnO}_{2}$ nanorods (d) [94].

catalytic performance, mainly because it has more surface $\mathrm{Mn}^{4+}$ ions as active sites and a higher surface area, as a result of its structure and morphology. Manganese oxides with pyrolusite, cryptomelane, and todorokite structures with different channel structures were also prepared (Fig. 16). Cryptomelane $\mathrm{MnO}_{2}$ has the best catalytic activity, mainly because its channel size matches that of HCHO molecules, rather than because of its surface area and reducibility [84]. The order of the catalytic activities of these $\mathrm{MnO}_{2}$ catalysts is cryptomelane $\left(\alpha-\mathrm{MnO}_{2}\right)>$ todorokite $\left(\delta-\mathrm{MnO}_{2}\right)>$ pyrolusite $\left(\beta-\mathrm{MnO}_{2}\right)$, because of their different crystalline structures. If the crystalline structure is unchanged but the morphology of pyrolusite $\mathrm{MnO}_{2}$ is changed to mesoporous, the catalytic activity order changes to pyrolusite (3D mesoporous $\left.\beta-\mathrm{MnO}_{2}\right)>$ cryptomelane $\left(\alpha-\mathrm{MnO}_{2}\right.$ nanorods) > pyrolusite $\left(\beta-\mathrm{MnO}_{2}\right.$ nanorods).

The structure and morphology clearly affect the catalytic activity in $\mathrm{HCHO}$ oxidation. There are many papers on the effects of morphology and structure on the catalytic activities of materials such as nest-like $\mathrm{MnO}_{2}$ [69], hollow $\mathrm{K}_{x} \mathrm{MnO}_{2}$ [88], OMS-2 [89,90], 3 $3 \mathrm{DOM} \mathrm{CeO}_{2}$ [72], 3D $\mathrm{Cr}_{2} \mathrm{O}_{3}$ [92], 3D $\mathrm{Co}_{3} \mathrm{O}_{4}$ [42], and $\mathrm{CeO}_{2}$ nanospheres [79].

\subsection{Effect of specific surface area}

A higher surface area exposes and disperses more noble-metal active sites and activates more $\mathrm{HCHO}$ molecules, and this can improve the catalytic activity in $\mathrm{HCHO}$ oxidation. This is why $\mathrm{TiO}_{2}, \mathrm{Al}_{2} \mathrm{O}_{3}$, and molecular sieves are commonly used as supports for noble-metal catalysts. Relatively cheap $\mathrm{Au}$ or Ag loaded on metal oxide supports with high surface areas have

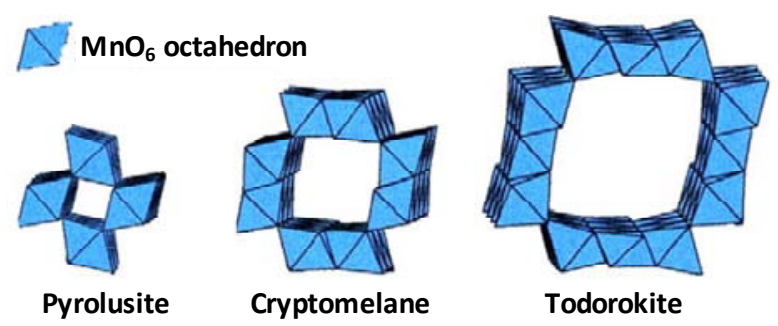

Fig. 16. Crystal structure models of three manganese oxides with different square tunnel sizes [84]. 


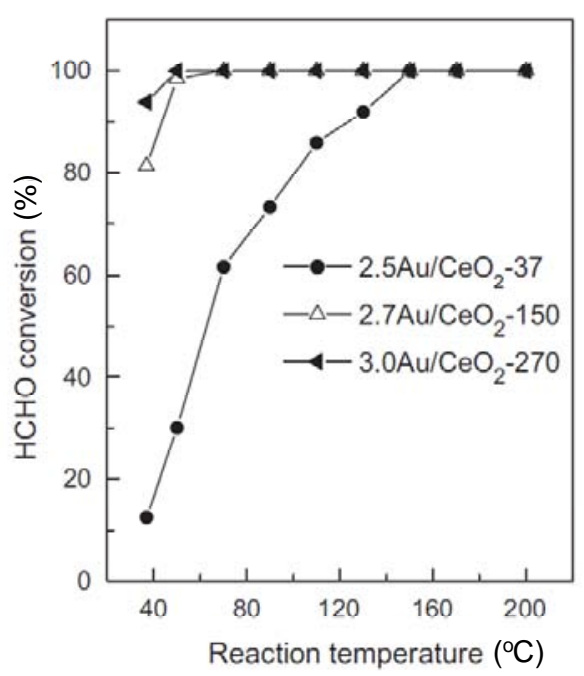

Fig. 17. Catalytic oxidation of $\mathrm{HCHO}$ over $\mathrm{Au} / \mathrm{CeO}_{2}$ catalysts [65].

good potential as catalysts. Li et al. [65] reported that $\mathrm{Ag} / \mathrm{CeO}_{2}$ catalysts with different surface areas showed different catalytic activities in HCHO oxidation (Fig. 17). A higher surface area favors the formation of $\mathrm{Au}$ species with high oxidation states and $\mathrm{Au}_{x} \mathrm{Ce}_{1-x} \mathrm{O}_{2-\delta}$ solid solutions.

Higher surface areas can also improve the catalytic activities of metal oxide catalysts by enhancing factors such as the reducibility, active phase, and oxygen species. Dai's group [92] prepared 3D mesoporous $\mathrm{Cr}_{2} \mathrm{O}_{3}$ with high surface areas (Table 3). $3 \mathrm{D} \mathrm{Cr}_{2} \mathrm{O}_{3}$ has better catalytic activity than bulk $\mathrm{Cr}_{2} \mathrm{O}_{3}$, which has a smaller surface area (5 $\left.\mathrm{m}^{2} / \mathrm{g}\right)$. Zhang et al. [72] prepared $3 \mathrm{DOM} \mathrm{CeO}_{2}$. The catalytic activity of $3 \mathrm{DOM} \mathrm{CeO}_{2}-80$ in $\mathrm{HCHO}$ oxidation is better than that of $3 \mathrm{DOM} \mathrm{CeO}_{2}-100$, because $3 \mathrm{DOM}$ $\mathrm{CeO}_{2}-80$ has a higher surface area. Our group reported that 3D $\mathrm{Co}_{3} \mathrm{O}_{4}$ [42], 3D $\mathrm{MnO}_{2}$ [94], and $\mathrm{CeO}_{2}$ nanosphere [79] catalysts gave good catalytic performances because of their low-temperature reducibilities and large numbers of metal cations, resulting from their high surface areas. Some studies of oxidation of other VOCs have also shown that a higher surface area improves the catalytic activity [101,102].

However, the surface area is not the decisive factor in catalytic oxidation. Sometimes a higher surface area does not result in a better catalytic performance. For instance, Yu et al. [69] prepared $\mathrm{MnO}_{2}$ catalysts with higher surface areas. Specific surface areas of cocoon-like $\mathrm{MnO}_{2}$, sea-urchin-like $\mathrm{MnO}_{2}$, and nest-like $\mathrm{MnO}_{2}$ are 247.6, 62.3 and $56.9 \mathrm{~m}^{2} / \mathrm{g}$, respectively. Fig. 18 shows that nest-like $\mathrm{MnO}_{2}$ has the smallest surface area and

Table 3

Textural properties of KIT- 6 and $\mathrm{Cr}_{2} \mathrm{O}_{3}$ catalysts [92].

\begin{tabular}{lccc}
\hline Sample & $\begin{array}{c}\text { Surface area } \\
\left(\mathrm{m}^{2} / \mathrm{g}\right)\end{array}$ & $\begin{array}{c}\text { Average pore } \\
\text { diameter }(\mathrm{nm})\end{array}$ & $\begin{array}{c}\text { Pore volume } \\
\left(\mathrm{cm}^{3} / \mathrm{g}\right)\end{array}$ \\
\hline KIT-6 & 790 & 6.1 & 0.95 \\
bulk-Cr & 5 & - & - \\
meso-Cr-200 & 91 & 7.7 & 0.13 \\
meso-Cr-300 & 98 & 7.6 & 0.14 \\
meso-Cr-400 & 124 & 7.9 & 0.21 \\
meso-Cr'-400 & 69 & 8.2 & 0.12 \\
meso-Cr-500 & 109 & 8.9 & 0.16 \\
\hline
\end{tabular}

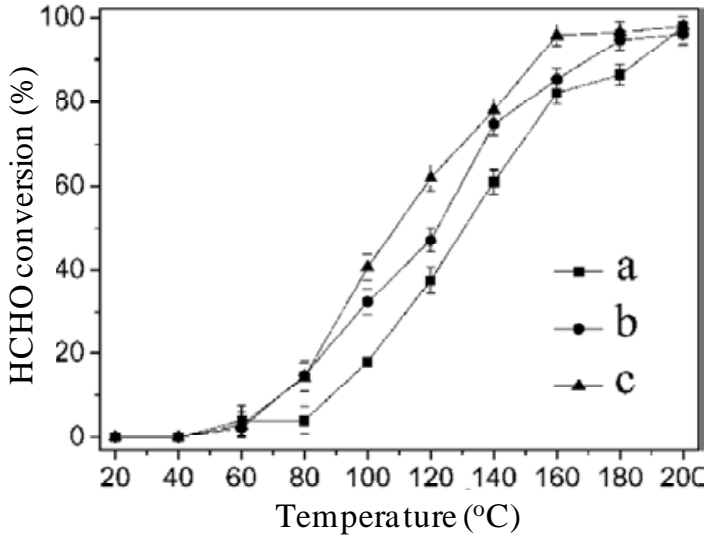

Fig. 18. Catalytic performances in $\mathrm{HCHO}$ oxidation of (a) cocoon-like $\mathrm{MnO}_{2}$, (b) sea-urchin-like $\mathrm{MnO}_{2}$, and (c) nest-like $\mathrm{MnO}_{2}$ [69].

the best catalytic activity; this is because the channels of width $0.6 \mathrm{~nm}$ are suitable for adsorption of HCHO molecules. Although cocoon-like $\mathrm{MnO}_{2}$ has the highest surface area, its low crystallinity prevents the formation of micropores.

\subsection{Effect of active sites}

The active sites are one of the decisive factors in determining the catalytic activity. A larger number of active sites can directly improve the oxidation abilities of catalysts, but this is a complex and abstract topic. In HCHO oxidation, noble metals (Pt, Pd, Au, and Ag) often provide better active sites. Most catalysts with Pt and Pd as active sites have excellent catalytic performances in the oxidation of HCHO and other VOCs because of the stronger ability of these metal atoms to activate $0-0$ and $\mathrm{C}-\mathrm{H}$ bonds $[103,104]$. The active sites of transition-metal oxide catalyst are usually provided by metal ions with high oxidation states. The activation ability of a noble metal is much stronger than those of high-valence transition-metal cations such as $\mathrm{Mn}^{4+}, \mathrm{Co}^{3+}$, and $\mathrm{Cr}^{6+}$. This is why addition of a noble metal can result in complete $\mathrm{HCHO}$ conversion at lower temperatures under normal circumstances.

In the Refs. [52,53,70,78,93], active sites are often defined as the number of noble-metal atoms or metal cations with high valence states on the catalyst surface. Generally, dispersion, which is related to the noble-metal particle size and loading, determines the number of active sites on a supported noble-metal catalyst. For example, Huang et al. [52] reported that a PdO-DP catalyst achieved higher HCHO conversion than a PdO-IMP catalyst, because of its higher Pd dispersion, which results in more active sites. The $\mathrm{Pd}-\mathrm{DP}-\mathrm{NaBH}_{4}$ catalyst has a higher TOF because of its higher Pd dispersion, Pd metallic state, and smaller particle size. Huang et al. [70] prepared a catalyst with stable single-atom Ag chains in HMO tunnels. Ag atoms replace $\mathrm{K}^{+}$ions in the channel structure of Mn octahedral sieves. The single Ag atoms at the openings of the tunnels of Ag-HMO nanorods are defined as active sites. The Ag-HMO catalyst has a better catalytic activity than a Ag/HMO catalyst with supported Ag nanoparticles, because the higher Ag dispersion increases the number of active sites. On transi- 
tion-metal oxide catalysts, surface metal cations with high valence states determine the number of active sites. Tang et al. [95] reported a $\mathrm{MnO}_{x}-\mathrm{CeO}_{2}$ sample that had good catalytic activity because of the large number of surface $\mathrm{Mn}^{4+}$ ions and lattice oxygen species. Our group reported that more metal cations clearly improved the HCHO oxidation activities on 3D $\mathrm{Co}_{3} \mathrm{O}_{4}$ [42] and $3 \mathrm{D} \mathrm{MnO}_{2}$ [94] catalysts.

\subsection{Effect of low-temperature reducibility}

Low-temperature reducibility is an important factor in oxidation reactions. Better reducibility means that oxygen species are easily activated or can easily migrate to the catalyst surface. It has been reported that better catalytic activity is related to lower-temperature reducibility. He's group reported that the reducibility of a $\mathrm{Na}-\mathrm{Pt} / \mathrm{TiO}_{2}$ catalyst correlated with its activity [46]. Fig. 19 shows that $\mathrm{Na}$ addition shifts the reduction peak to lower temperature. Tang's group prepared $\mathrm{Ag} / \mathrm{MnO}_{x}-\mathrm{CeO}_{2}$ [63], which has good catalytic activity because of its low-temperature reducibility. $\mathrm{Ag} / \mathrm{MnO}_{x}-\mathrm{CeO}_{2}$ shows a reduction peak at $293{ }^{\circ} \mathrm{C}$. The presence of $\mathrm{Ag}$ shifts the reduction peak to lower temperature compared with that for $\mathrm{MnO}_{x}-\mathrm{CeO}_{2}$, because of interactions between $\mathrm{Ag}$ and $\mathrm{MnO}_{x}-\mathrm{CeO}_{2}$. Dai's group reported that $3 \mathrm{D} \mathrm{Cr}_{2} \mathrm{O}_{3}$ calcined at $400{ }^{\circ} \mathrm{C}$ had the best catalytic activity in $\mathrm{HCHO}$ oxidation among a group of $\mathrm{Cr}$ catalysts calcined at different temperatures [92]. The initial $\mathrm{H}_{2}$ consumption rate was used to evaluate the catalyst reducibilities. The order of the initial $\mathrm{H}_{2}$ consumption rates is $\mathrm{Cr}-400>$ Cr-300 > Cr-500 > Cr-200 > bulk Cr, which indicates that 3D $\mathrm{Cr}-400$ has the best reducibility, which correlates with the catalytic activities. Our group also reported that a $\mathrm{K}-\mathrm{Ag} / \mathrm{Co}_{3} \mathrm{O}_{4}$ catalyst has the best activity and low-temperature reducibility of all samples examined [78]. The addition of $\mathrm{K}^{+}$ions shifts the reduction peak to lower temperature.

\subsection{Effect of surface oxygen species}

A large number of surface oxygen species improves the catalytic activity. The adsorption, activation, and migration of oxygen during the oxidation reaction is complex. The consump-

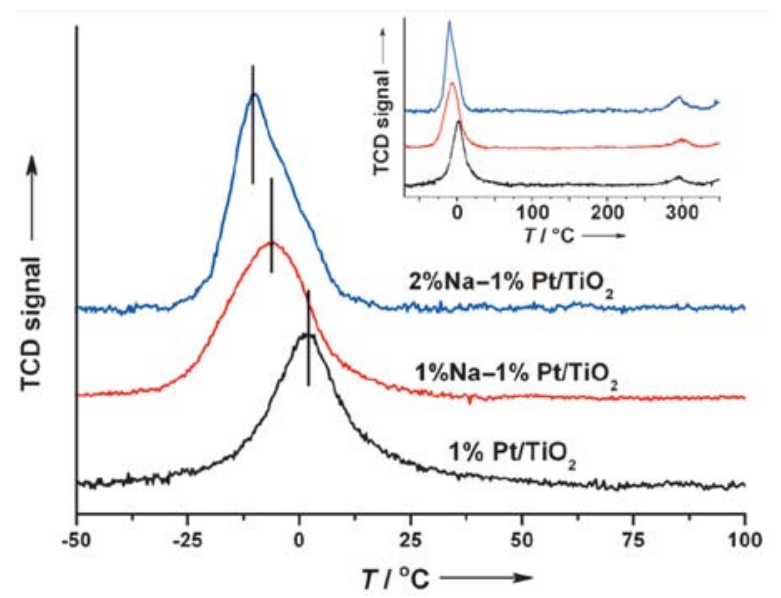

Fig. 19. $\mathrm{H}_{2}$-temperature-programmed reduction profiles of $x$ wt $\%$ $\mathrm{Na}-1 \% \mathrm{Pt} / \mathrm{TiO}_{2}(x=0,1$, and 2) [46]. tion and supply of oxygen species occur continuously on the catalyst surface. Generally, a catalyst with abundant surface oxygen species has better activity than one with few such species in the catalytic oxidation of HCHO.

Our group loaded $\mathrm{Ag}$ nanoparticles on $3 \mathrm{D} \mathrm{Co}_{3} \mathrm{O}_{4}$ [78]. $\mathrm{Ag} / \mathrm{Co}_{3} \mathrm{O}_{4}$ has more surface lattice oxygen species because of the presence of $\mathrm{Ag}$, and has better catalytic activity than $3 \mathrm{D}$ $\mathrm{Co}_{3} \mathrm{O}_{4}$. The addition of $\mathrm{K}^{+}$ions to $\mathrm{Ag} / \mathrm{Co}_{3} \mathrm{O}_{4}$ gave $\mathrm{K}-\mathrm{Ag} / \mathrm{Co}_{3} \mathrm{O}_{4}$ has a large number of surface hydroxyls as surface adsorbed oxygen species, because of the presence of $\mathrm{K}^{+}$ions, and shows better activity than $\mathrm{Ag} / \mathrm{Co}_{3} \mathrm{O}_{4}$. Surface adsorption and lattice oxygen species on $\mathrm{K}-\mathrm{Ag} / \mathrm{Co}_{3} \mathrm{O}_{4}$ are involved in the activation and migration of oxygen, and this increases the oxidation activity in HCHO. Zhang et al. [46] added $\mathrm{Na}^{+}$ions to $\mathrm{Pt} / \mathrm{TiO}_{2}$, which provided abundant surface hydroxyls on the $\mathrm{Na}-\mathrm{Pt} / \mathrm{TiO}_{2}$ catalyst. $\mathrm{Na}-\mathrm{Pt} / \mathrm{TiO}_{2}$ shows the best activity in $\mathrm{HCHO}$ oxidation. Surface hydroxyls as active oxygen species directly change the reaction route of HCHO oxidation. Different preparation methods lead to different surface oxygen species. Large amounts of surface chemisorbed oxygen form on $\mathrm{Ag} / \mathrm{CeO}_{2}$ [79] and 3D $\mathrm{Co}_{3} \mathrm{O}_{4}$ [42], and this improves their catalytic activity in $\mathrm{HCHO}$ oxidation.

\subsection{Effects of experimental parameters}

Different experimental parameters such as water vapor content, initial HCHO concentration, and space velocity, can lead to different HCHO conversions. Generally, catalytic conversion of HCHO decreases with increasing initial HCHO concentration and GHSV. Huang et al. [52] examined the effect of initial HCHO concentration in the range 5-30 ppm. The steady conversions of $\mathrm{HCHO}$ were $100 \%$ at $5 \mathrm{ppm}, 99.1 \%$ at $10 \mathrm{ppm}$, $98.2 \%$ at $20 \mathrm{ppm}$, and $95.8 \%$ at $30 \mathrm{ppm}$. As anticipated, the HCHO removal efficiency decreased with increasing initial HCHO concentration. The effect of GHSV on HCHO oxidation was investigated using $0.1 \% \quad \mathrm{Pt}-\mathrm{TiO}_{2}$ in the range 40000-240000 $\mathrm{h}^{-1}$. The steady conversions of HCHO were $100 \%$ at $40000 \mathrm{~h}^{-1}, 99.1 \%$ at $80000 \mathrm{~h}^{-1}, 97.8 \%$ at $160000 \mathrm{~h}^{-1}$, and $90.5 \%$ at $240000 \mathrm{~h}^{-1}$. The HCHO conversion decreased with increasing GHSV. Tang et al. [62] investigated the effect of HCHO concentration. They achieved $100 \%$ conversion of HCHO at $\mathrm{HCHO}$ concentrations less than $100 \mathrm{ppm}$; the conversion decreased slightly with increasing HCHO concentration. The HCHO conversion was $50 \%$ at an HCHO concentration of 580 ppm. The HCHO conversion decreased with increasing feed concentration. Xia et al. [92] examined the effects of GHSV on HCHO, acetone, and methanol oxidation in the range 10000-60000 $\mathrm{h}^{-1}$. The results confirm that conversion over 3D $\mathrm{Cr}_{2} \mathrm{O}_{3}$ decreased with increasing of GHSV.

For the catalytic oxidation of other VOCs such as ethanol $[93,105], \mathrm{CH}_{4}$ [101], and toluene [106], the addition of water vapor shifts complete conversion to higher temperatures. The VOC conversion decreases with increasing water vapor content. However, the presence of water vapor improves HCHO conversion. Huang et al. [52] studied the effect of moisture. HCHO oxidation was promoted by water vapor up to $50 \%$ humidity. Nearly $100 \%$ HCHO conversion was achieved at humidities of 
$25 \%$ and $50 \%$, but the conversion was only $45.2 \%$ at the stable stage at $0 \%$ humidity. The HCHO conversion decreased slightly at humidities higher than $50 \%$ because of coverage of active centers by water, but the removal efficiency was still as high as $95.6 \%$ at $97.5 \%$ humidity. The presence of moisture did not inhibit, but enhanced, $\mathrm{HCHO}$ oxidation at room temperature.

The catalytic activities in HCHO oxidation of different catalysts were compared under the same conditions. Changes in the GHSV and initial HCHO concentration hinder comparison of the oxidation activities of various catalysts. Normalized rates, i.e., $\mathrm{mol} /\left(\mathrm{m}^{2} \cdot \mathrm{h}\right)$ or $\mathrm{mol} /\left(\mathrm{m}^{2} \cdot \mathrm{s}\right)$, and TOFs $\left(\mathrm{s}^{-1}\right.$ or $\left.\mathrm{h}^{-1}\right)$ should therefore be used calculate HCHO oxidation activities. In real situations, water vapor is often present in indoor environments and vehicle exhausts. It is therefore necessary to examine the effect of moisture on catalytic activity.

\section{Reaction mechanism}

Research on the mechanism of HCHO oxidation is a sophisticated process. Several mechanisms have been proposed based on the Mars-van Krevelen mechanism. He's group [45] reported the reaction mechanism on $\mathrm{TiO}_{2}$-supported noble-metals catalysts (Fig. 20). Dioxymethylene, formate, and adsorbed CO are important reaction intermediates in HCHO oxidation. The decomposition of surface formate species to adsorbed $\mathrm{CO}$ on the catalyst is the rate-determining step for catalytic oxidation of HCHO. HCHO is oxidized to surface dioxymethylene species, and then formate species. The surface formate species decompose to adsorbed $\mathrm{CO}$ species and $\mathrm{H}_{2} \mathrm{O}$, and then the $\mathrm{CO}$ species react with $\mathrm{O}_{2}$ to produce gas-phase $\mathrm{CO}_{2}$. $\mathrm{Pt} / \mathrm{TiO}_{2}$ shows high activity in $\mathrm{HCHO}$ oxidation because decomposition of formate species is easier on this catalyst than on supported catalysts containing $\mathrm{Rh}, \mathrm{Pd}$, and $\mathrm{Au}$. The same group reported that the reaction mechanism over a $\mathrm{Na}-\mathrm{Pt} / \mathrm{TiO}_{2}$ catalyst differed from that on a $\mathrm{Pt} / \mathrm{TiO}_{2}$ catalyst [46]. $\mathrm{Na}-\mathrm{Pt} / \mathrm{TiO}_{2}$ has the best catalytic activity in $\mathrm{HCHO}$ oxidation because of the surface hydroxyl groups formed by $\mathrm{Na}^{+}$ions; the reaction mechanism differs from that over $\mathrm{Pt} / \mathrm{TiO}_{2}$ because of the addition of $\mathrm{Na}$. The HCHO oxidation reaction on $\mathrm{Na}$-free $\mathrm{Pt} / \mathrm{TiO}_{2}$ follows the formate decomposition route ( $\mathrm{HCHO} \rightarrow \mathrm{CHOO}^{-} \rightarrow \mathrm{CO} \rightarrow \mathrm{CO}_{2}$ ), with formate decomposition to $\mathrm{CO}$ being the rate-determining step. However, $\mathrm{HCHO}$ oxidation over $2 \% \mathrm{Na}-1 \% \mathrm{Pt} / \mathrm{TiO}_{2}$ follows a different pathway, $\mathrm{HCHO} \rightarrow \mathrm{CHOO}^{-}+\bullet \mathrm{OH} \rightarrow \mathrm{CO}_{2}+\mathrm{H}_{2} \mathrm{O}$. The reaction between surface hydroxyls and formate is easier than decomposition of formate to $\mathrm{CO}$ followed by $\mathrm{CO}$ oxidation. The process in which formate species on the catalyst surface directly react with surface hydroxyl groups to form $\mathrm{CO}_{2}$ and $\mathrm{H}_{2} \mathrm{O}$ becomes the rate-determining step. Nie et al. [47] reported the

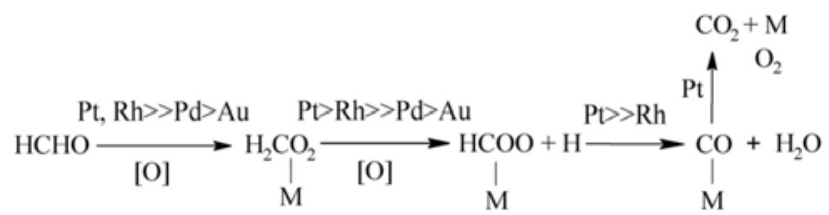

Fig. 20. Reaction scheme for catalytic oxidation of $\mathrm{HCHO}$ on $\mathrm{TiO}_{2}$-supported Pt, Rh, Pd, and Au catalysts [45]. same reaction mechanism for $\mathrm{HCHO}$ oxidation on the $\mathrm{Na}-\mathrm{Pt} / \mathrm{TiO}_{2}$ catalyst.

Our group [78] reported the reaction mechanism for $\mathrm{HCHO}$ oxidation on a $3 \mathrm{D} \mathrm{K}-\mathrm{Ag} / \mathrm{Co}_{3} \mathrm{O}_{4}$ catalyst (Fig. 21). $\mathrm{K}-\mathrm{Ag} / \mathrm{Co}_{3} \mathrm{O}_{4}$ has a large number of $\mathrm{Ag}$ (111) crystal facets, surface lattice oxygen $\left(\mathrm{O}^{2-}\right)$ species, and $\mathrm{Co}^{3+}$ cations because of the addition of $\mathrm{K}^{+}$ions; these are all involved in the oxidation reaction. $\mathrm{K}^{+}$ ion addition changes the reaction route of $\mathrm{HCHO}$ oxidation on $3 \mathrm{D} \mathrm{K}-\mathrm{Ag} / \mathrm{Co}_{3} \mathrm{O}_{4}$ catalyst, as in the case of $2 \% \mathrm{Na}-1 \% \mathrm{Pt} / \mathrm{TiO}_{2}$ catalyst [46]. Research shows that more $\mathrm{Co}^{3+}$ cations can increase the oxygen vacancy density; these vacancies result from anionic structural defects. The oxygen vacancies directly participate in the adsorption, activation, and migration of oxygen. The Ag (111) planes are active faces in HCHO oxidation and can activate the $\mathrm{O}^{2-}$ species of $3 \mathrm{D}^{-} \mathrm{Co}_{3} \mathrm{O}_{4}$. The $\mathrm{O}^{2-}$ species can also improve the reactivity of the Ag (111) surfaces, enhance the breakage of $\mathrm{H}_{2}, \mathrm{O}_{2}$, and NO bonds, and strengthen the bonding of $\mathrm{H}, \mathrm{O}, \mathrm{N}$, and $\mathrm{C}$ atoms to the Ag (111) surface. In the reaction, the active $\mathrm{O}^{2-}$ species around $\mathrm{Ag}$ are directly depleted and replenished by the $\mathrm{Co}_{3} \mathrm{O}_{4}$ support, which acts as an oxygen reservoir. The activation and migration of oxygen species at the oxygen vacancies depend on the $\mathrm{Co}^{3+} / \mathrm{Co}^{2+}$ and $\mathrm{Ag}^{+} / \mathrm{Ag}^{0}$ redox cycles after the $\mathrm{O}^{2-}$ species are consumed (Fig. 21, yellow box). The redox cycle is possibly the same as the $\mathrm{Mn}^{4+} / \mathrm{Mn}^{3+}$ and $\mathrm{Ce}^{4+} / \mathrm{Ce}^{3+}$ redox cycles reported by Tang et al. [62]. The increase in the number of $\mathrm{Co}^{3+}$ ions favors the formation of oxygen vacancies, which can enhance the $\mathrm{Co}^{3+} / \mathrm{Co}^{2+}$ and $\mathrm{Ag}^{+} / \mathrm{Ag}^{0}$ redox cycles. In addition, the addition of $\mathrm{K}^{+}$ions results in the presence on the $\mathrm{K}-\mathrm{Ag} / \mathrm{Co}_{3} \mathrm{O}_{4}$ catalyst surface of adsorbed oxygen species, in the form of hydroxyl species. Surface hydroxyl species play a critical role in the reaction path of HCHO oxidation. A surface hydroxyl can immediately react with formate species on the $\mathrm{K}-\mathrm{Ag} / \mathrm{Co}_{3} \mathrm{O}_{4}$ surface to form a molecule of $\mathrm{CO}_{2}$ and $\mathrm{H}_{2} \mathrm{O}$. This is similar to the reaction path for the $\mathrm{Na}-\mathrm{Pt} / \mathrm{TiO}_{2}$ catalyst [46]. The difference is that $\mathrm{O}^{2-}$ species at the perimeter of $\mathrm{Ag}$ in $\mathrm{K}-\mathrm{Ag} / \mathrm{Co}_{3} \mathrm{O}_{4}$ participate in $\mathrm{HCHO}$ oxidation because of strong interactions between $\mathrm{Ag}$ with $\mathrm{Co}$ and anionic lattice defects. The TOFs of $\mathrm{K}-\mathrm{Ag} / \mathrm{Co}_{3} \mathrm{O}_{4}$, especially $1.7 \% \mathrm{~K}-\mathrm{Ag} / \mathrm{Co}_{3} \mathrm{O}_{4}$, are much higher than that of $\mathrm{Ag} / \mathrm{Co}_{3} \mathrm{O}_{4}$. It is concluded that at low temperature $\left(<80{ }^{\circ} \mathrm{C}\right)$, the catalytic activity of $\mathrm{K}-\mathrm{Ag} / \mathrm{Co}_{3} \mathrm{O}_{4}$ in $\mathrm{HCHO}$ oxidation largely depends on surface $\bullet \mathrm{OH}$ species at the perimeters of $\mathrm{Ag}$ (111) facets; at higher temperatures (>80 ${ }^{\circ} \mathrm{C}$ ), the surface $\bullet \mathrm{OH}$ species are consumed and replaced quickly, and their supply relies on the migration of $\mathrm{O}^{2-}$ species from the $3 \mathrm{D} \mathrm{Co}_{3} \mathrm{O}_{4}$ support. The reaction pathway of $\mathrm{HCHO}$ oxidation on $\mathrm{K}-\mathrm{Ag} / \mathrm{Co}_{3} \mathrm{O}_{4}$ is therefore $\mathrm{HCHO} \rightarrow \mathrm{CHOO}^{-}+\bullet \mathrm{OH} \rightarrow \mathrm{CO}_{2}+$ $\mathrm{H}_{2} \mathrm{O}$. For $\mathrm{Ag} / \mathrm{Co}_{3} \mathrm{O}_{4}$, the reaction pathway is $\mathrm{HCHO} \rightarrow \mathrm{CHOO}^{-} \rightarrow$

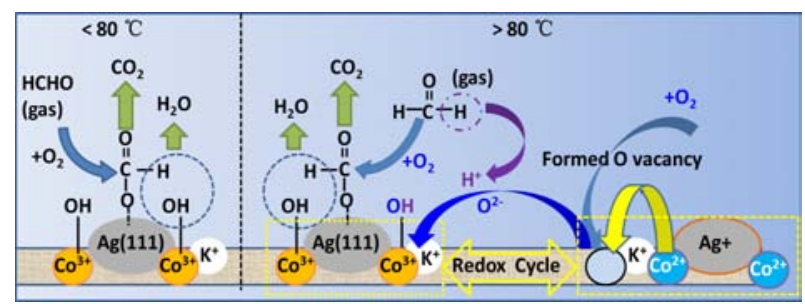

Fig. 21. Reaction pathway on $\mathrm{K}-\mathrm{Ag} / \mathrm{Co}_{3} \mathrm{O}_{4}$ catalyst [78]. 
$\mathrm{CO}+\mathrm{O}^{*} \rightarrow \mathrm{CO}_{2}$. The $\mathrm{O}^{2-}$ species play an important role on the oxidation reaction and active $0^{*}$ species are often involved in complex migration though oxygen vacancies. The TOFs of $\mathrm{Ag} / \mathrm{Co}_{3} \mathrm{O}_{4}$ show that the catalytic activity depends on the $\mathrm{O}^{2-}$ species around $\mathrm{Ag}$ nanoparticles at low temperature $\left(<90{ }^{\circ} \mathrm{C}\right)$, and on the $\mathrm{O}^{2-}$ species at the perimeter of $\mathrm{Ag}$, which migrate from the $3 \mathrm{D} \mathrm{Co}_{3} \mathrm{O}_{4}$ support at higher temperatures $\left(>90^{\circ} \mathrm{C}\right)$.

Liu et al. [73] reported the mechanism of HCHO oxidation on a $3 \mathrm{DOM} \mathrm{Au} / \mathrm{CeO}_{2}$ catalyst (Fig. 22). HCHO oxidation occurs via two processes, catalyzed by ionic $\mathrm{Au}^{3+}$ and metallic $\mathrm{Au}^{0}$, respectively; $\mathrm{Au}^{3+}$ shows higher catalytic activity. The $\mathrm{CeO}_{2}$ support in contact with $\mathrm{Au}^{3+}$ may be partly reduced to $\mathrm{Ce}_{2} \mathrm{O}_{3}$ when $\mathrm{Au}^{3+}$ ions are formed on the surface of the $3 \mathrm{DOM} \mathrm{Au} / \mathrm{CeO}_{2}$ catalyst. After adsorption of $\mathrm{HCHO}$ molecules on the surface of the $\mathrm{CeO}_{2}$ support, active oxygen may be transferred from $\mathrm{Au}_{2} \mathrm{O}_{3}$ to $\mathrm{HCHO}$ to form $\mathrm{HCOOH}$ and $\mathrm{Au}^{0}$. $\mathrm{HCOOH}$ is then converted to formate through interactions with the $\mathrm{CeO}_{2}$ support, accompanied by loss of $\bullet \mathrm{H}$ to form $\mathrm{H}_{2} \mathrm{O}$ with free $\bullet \mathrm{OH}$ adsorbed on the surface of the $\mathrm{CeO}_{2}$ support. Incomplete oxidation of $\mathrm{HCOOH}$ also occurs, which enables conversion of $\mathrm{HCOOH}$ to carbonate and hydrocarbonate. $\mathrm{H}_{2} \mathrm{O}$ is generated when the lost $\bullet \mathrm{H}$ interacts with free $\bullet \mathrm{OH}$. $\mathrm{HCHO}$ is converted to $\mathrm{CO}_{2}$ and $\mathrm{H}_{2} \mathrm{O}$ via this cycle. The $\mathrm{Au}^{3+}$ in the $3 \mathrm{DOM} \mathrm{Au} / \mathrm{CeO}_{2}$ catalyst determines the efficiency of the HCHO conversion. HCHO oxidation catalyzed by metallic $\mathrm{Au}^{0}$ via another process is also involved, but is not the dominant process. After $\mathrm{HCHO}$ adsorption on the $\mathrm{CeO}_{2}$ support, active oxygen is transferred to $\mathrm{HCHO}$ to form $\mathrm{HCOOH}$, and then $\mathrm{HCOOH}$ is converted to $\mathrm{CO}_{2}$ and $\mathrm{H}_{2} \mathrm{O}$, completing the oxidation process. Incomplete oxidation occurs simultaneously to form carbonate and hydrocarbonate, which may deactivate the $3 \mathrm{DOM} \mathrm{Au} / \mathrm{CeO}_{2}$ catalyst. In the $\mathrm{HCHO}$ oxidation process, there is a balance between $\mathrm{HCOOH}$ adsorption and desorption, to form formate on the $\mathrm{CeO}_{2}$ support. $\mathrm{HCOOH}$ can therefore be converted to $\mathrm{CO}_{2}$ and $\mathrm{H}_{2} \mathrm{O}$ through complete oxidation, and formate can be converted to carbonate and hydrocarbonate via incomplete oxidation; these are deposited on the surface of the $\mathrm{CeO}_{2}$ support and deactivate the catalyst. Blockage of the active sites on $3 \mathrm{DOM} \mathrm{Au} / \mathrm{CeO}_{2}$ by carbonate and hydrocarbonate is difficult, because of the macroporous structure of the catalyst.

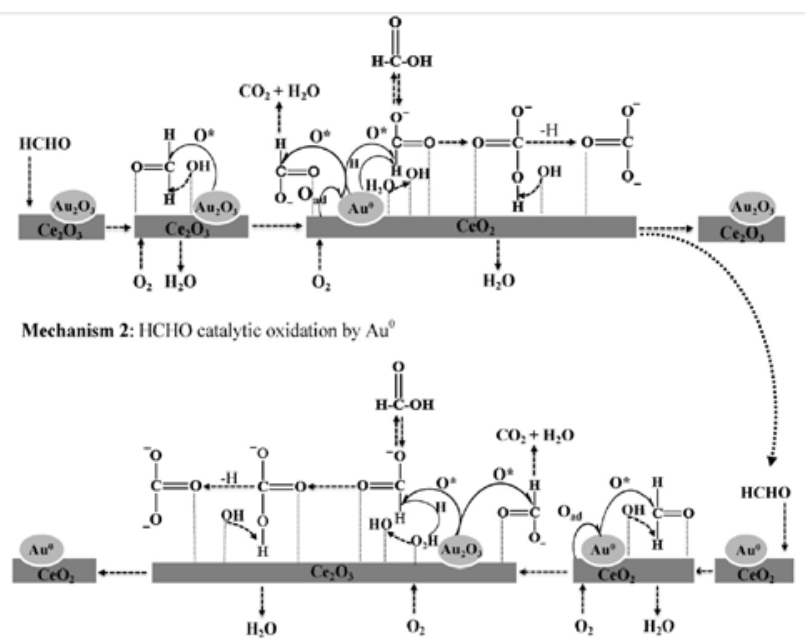

Fig. 22. Mechanism of $\mathrm{HCHO}$ oxidation on 3DOM Au/ $/ \mathrm{CeO}_{2}$ catalyst [73].

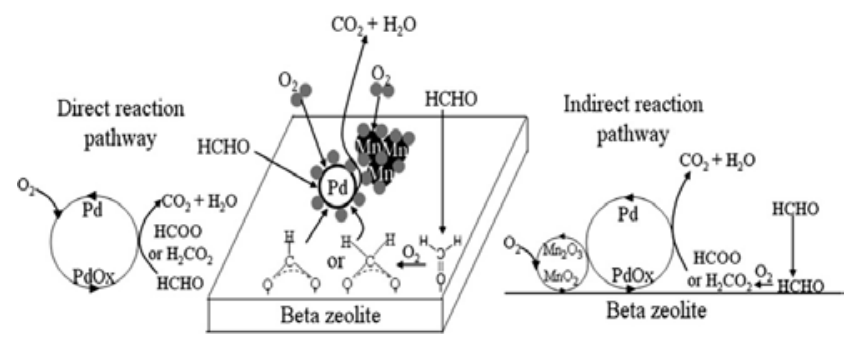

Fig. 23. HCHO oxidation pathway over $0.25 \mathrm{Pd} / 20 \mathrm{Mn} /$ Bata catalyst [54].

According to the literature, the addition of $\mathrm{Na}^{+}$or $\mathrm{K}^{+}$ions, which results in formation of hydroxyl oxygen species on the catalyst surface, can change the reaction route and increase the catalytic activity. This can be used to help design methods for catalyst preparation. Perhaps the HCHO oxidation activities of other supported noble-metal catalysts could be increased by alkali metal addition. In HCHO oxidation, abundant surface oxygen species participate in the oxidation reaction, and this enhances the catalytic activity. Surface-active oxygen species depend on the redox cycles of high- and low-valent states of metal cations, and this directly affects the adsorption, activation, and migration of oxygen species. Park et al. [54] reported indirect and direct reaction pathways over a $0.25 \mathrm{Pd} / 20$ $\mathrm{Mn} /$ Bata catalyst; these are two types of redox cycle, and the cycle depends on whether Mn cations participate in the reaction at a given temperature (Fig. 23). Tang et al. [62,63] proposed two redox cycles for $\mathrm{HCHO}$ oxidation over $\mathrm{Pt} / \mathrm{MnO}_{x}-\mathrm{CeO}_{2}$ and $\mathrm{Ag} / \mathrm{MnO}_{x}-\mathrm{CeO}_{2}$ catalysts to explain the formation of active oxygen; these are displayed in Fig. 24. HCHO oxidation over different catalysts may involve different reaction mechanisms, probably because different active oxygen species and sites can form different reaction intermediates. Formate species are important reaction intermediates in HCHO oxidation; they are present on all reported catalysts, and can produce different intermediates on different catalysts. There are three processes. (1) Formate species can decompose to adsorbed CO followed by $\mathrm{CO}$ oxidation on the surfaces of catalysts such as $\mathrm{Pt} / \mathrm{TiO}_{2}$ [45] and $\mathrm{Ag} / \mathrm{Co}_{3} \mathrm{O}_{4}$ [78]. (2) Formate species can react with surface hydroxyls to form $\mathrm{CO}_{2}$ and $\mathrm{H}_{2} \mathrm{O}$ directly on the surfaces of catalysts such as $\mathrm{Na}-\mathrm{Pt} / \mathrm{TiO}_{2}$ [46] and $\mathrm{K}-\mathrm{Ag} / \mathrm{Co}_{3} \mathrm{O}_{4}$ [78]. (3) Formate species can form carbonate and then decompose to $\mathrm{CO}_{2}$ on the surfaces of catalysts such as 3DOM Au/CeO $[73]$ and $2 \mathrm{D} \mathrm{Au} / \mathrm{Co}_{3} \mathrm{O}_{4}-\mathrm{CeO}_{2}$. The mechanism of $\mathrm{HCHO}$ oxidation on a $2 \mathrm{D} \mathrm{Au} / \mathrm{Co}_{3} \mathrm{O}_{4}-\mathrm{CeO}_{2}$ catalyst was reported by $\mathrm{Ma}$ et al. [75]. As shown in Fig. 25, HCHO is oxidized to formate species, which

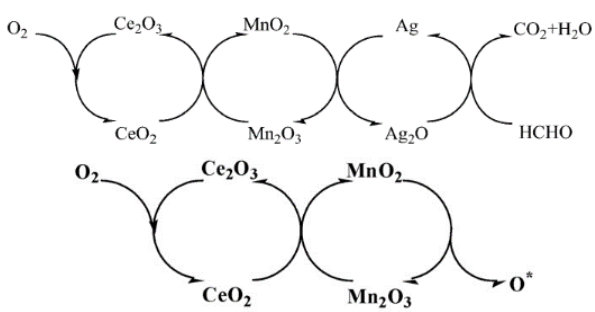

Fig. 24. Redox cycles in $\mathrm{HCHO}$ oxidation over $\mathrm{MnO}_{x}-\mathrm{CeO}_{2}$ and $\mathrm{Ag} / \mathrm{MnO}_{x}-\mathrm{CeO}_{2}[62,63]$. 


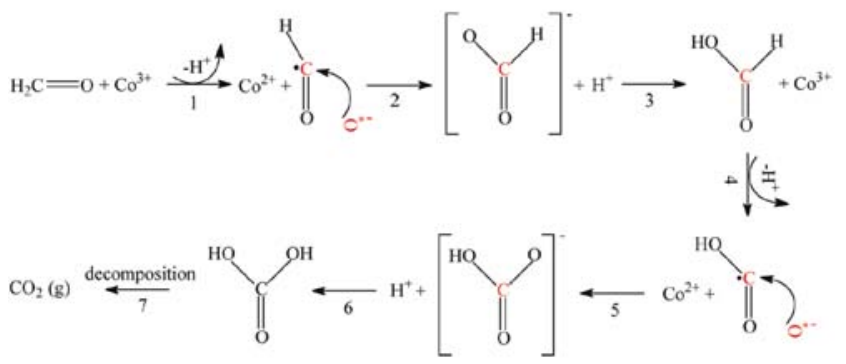

Fig. 25. Reaction route for HCHO oxidation over mesoporous $\mathrm{Au} / \mathrm{Co}_{3} \mathrm{O}_{4}-\mathrm{CeO}_{2}$ [75].

form carbonate. The carbonate decomposes to $\mathrm{CO}_{2}$ and $\mathrm{OH}^{-}$. Further studies are needed to enable a deeper understanding of the mechanism of $\mathrm{HCHO}$ oxidation. The reaction mechanisms over more catalysts need to be clarified to obtain a more comprehensive understanding.

\section{Results and outlook}

HCHO is a carcinogenic and teratogenic substance, and has strong photochemical activity. It is emitted during the production of textiles, agrochemicals, sheet materials, and fine chemicals, from motor vehicle exhausts, and from various indoor decorating materials. HCHO removal is necessary to protect human health and the atmospheric environment. The removal of HCHO through catalytic oxidation is a more promising technique than adsorption methods. The key to this technique is the development of suitable catalysts. Catalytic materials for HCHO oxidation can be divided into noble-metal and transition-metal oxide systems. Noble-metal catalysts are generally prepared by loading noble metals (Pt, $\mathrm{Pd}, \mathrm{Au}$, and $\mathrm{Ag}$ ) on various supports. Supports can be classified as common supports, traditional metal oxide supports, and metal oxide support with special morphologies. The common supports used in HCHO oxidation are usually materials such as $\mathrm{SiO}_{2}, \mathrm{Al}_{2} \mathrm{O}_{3}, \mathrm{TiO}_{2}$, and molecular sieves. These have large surface areas, and this is conducive to the exposure of active sites and the adsorption and diffusion of reactants and products, and can enhance the synergistic effect between the support and the active component. The catalytic HCHO oxidation activities of different noble-metal catalysts loaded on common supports decrease in the following order: $\mathrm{Pt}$ $>\mathrm{Pd}>\mathrm{Rh}>\mathrm{Au}>\mathrm{Ag}$. This type of catalyst is suitable for applications in indoor environments and factories, and for vehicle exhausts, except in terms of cost and thermostability. $\mathrm{Na}-\mathrm{Pt} / \mathrm{TiO}_{2}$ [46], which is used in air purifiers, is the best catalyst for $\mathrm{HCHO}$ removal, followed by $\mathrm{Pt} / \mathrm{TiO}_{2}$ and $\mathrm{Pd} / \mathrm{TiO}_{2}$ [53]. The use of different supports with the same active components directly affects the activities of catalysts for HCHO oxidation. Precious metals have been loaded on metal oxide supports with the aim of obtaining the advantages of both noble-metal and metal oxide catalysts; such catalysts have better low-temperature oxidation activities and thermostabilities because of the interactions between the metal and the support. Metal oxide supports such as $\mathrm{CeO}_{2}, \mathrm{Fe}_{2} \mathrm{O}_{3}, \mathrm{Co}_{3} \mathrm{O}_{4}$, and $\mathrm{MnO}_{2}$, or their composites, prepared by conventional precipitation, coprecipitation, or sol-gel methods, used in HCHO oxidation are defined as tra- ditional metal oxide supports. This type of supported Pt catalyst has excellent catalytic activity $\left(T_{50}\right)$ at room temperature; examples are $\mathrm{Pt} / \mathrm{MnO}_{x}-\mathrm{CeO}_{2}$ [62] and $\mathrm{Pt} / \mathrm{Fe}_{2} \mathrm{O}_{3}$ [67]. Although supported Pt catalysts are promising for various applications, they are too expensive and their industrial production and use are limited. If the Pt loading is decreased to reduce the production cost, the reaction performance of the catalyst may be compromised. Some catalysts with traditional metal oxide supports, such as $\mathrm{Au} / \mathrm{CeO}_{2}$ [65], $\mathrm{Ag} / \mathrm{MnO}_{x}-\mathrm{CeO}_{2}$ and $\mathrm{Ag} / \mathrm{CeO}_{2}$ [63], have better development potential, because of the strong interactions between the noble metal and the support. The choice of support for HCHO oxidation catalysts is important. The trend is not to choose Pt or Pd as the active components of catalysts of HCHO removal, and supported Au or Ag catalysts may provide suitable alternatives. Traditional metal oxide supports can be modified by using different preparation methods. Metal oxides with special morphologies and structures, such as nanorods, nanospheres, mesopores, and macropores, are mainly prepared using hydrothermal and hard template methods. Such materials may provide new supports with catalytic activities better than those of conventional bulk metal oxides prepared using precipitation methods. Few Pt catalysts have been produced using metal oxide supports with special morphologies, because $2 \% \mathrm{Na}-1 \% \mathrm{Pt} / \mathrm{TiO}_{2}$ has become the benchmark for supported Pt catalysts in air purification [46]. More attention has been paid to catalysts consisting of $\mathrm{Ag}$ and $\mathrm{Au}$ loaded on metal oxide supports with special morphologies. These catalysts, e.g., mesoporous 3DOM $\mathrm{Au} / \mathrm{CeO}_{2}-\mathrm{Co}_{3} \mathrm{O}_{4}$ [74], 2D $\mathrm{Au} / \mathrm{Co}_{3} \mathrm{O}_{4}-\mathrm{CeO}_{2}, 2 \mathrm{D} \mathrm{Au} / \mathrm{Co}_{3} \mathrm{O}_{4}$ [75], and 3D $\mathrm{K}-\mathrm{Ag} / \mathrm{Co}_{3} \mathrm{O}_{4}$ [78], have excellent catalytic activities in room-temperature $\mathrm{HCHO}$ oxidation $\left(T_{50}=\right.$ room temperature $)$ and have good potential applications.

Transition-metal oxide catalysts have cheap and plentiful sources, and have been widely studied. Single transition-metal oxide catalysts such as $\mathrm{MnO}_{2}$ nanorods, cryptomelane nanospheres, and mesorporous $\mathrm{MnO}_{2}, \mathrm{Co}_{3} \mathrm{O}_{4}$, and $\mathrm{Cr}_{2} \mathrm{O}_{3}$ have good catalytic activities in $\mathrm{HCHO}$ oxidation, and their $T_{50}$ and $T_{100}$ HCHO conversions are less than or equal to 110 and $140{ }^{\circ} \mathrm{C}$, respectively. Their catalytic activities are superior to those of traditional metal oxide catalysts synthesized using precipitation methods, because of their special morphologies and structures, higher surface areas, and other factors that improve the catalytic activity. Single transition-metal oxide catalysts with special morphologies have good application prospects because they are cheap and give better catalytic performances. Some metal elements (such as $\mathrm{Ce}, \mathrm{Sn}, \mathrm{Cu}$, and $\mathrm{Zr}$ ) can be doped into $\mathrm{MnO}_{x}$ and $\mathrm{Co}_{3} \mathrm{O}_{4}$ to prepare composite metal oxides when a single metal oxide does not give a good catalytic performance. The composite metal oxide catalyst $\mathrm{MnO}_{x}-\mathrm{CeO}_{2}[95,96]$ has excellent catalytic activity $\left(T_{50}<100{ }^{\circ} \mathrm{C}\right)$ because the strong interactions between $\mathrm{MnO}_{x}$ and $\mathrm{CeO}_{2}$ change the number of surface-active oxygen species and the active phase. Few composite metal oxide catalysts have been reported; therefore, the development of composite metal oxide catalysts with special morphologies for lower-temperature catalytic activities is an area for future exploration. The use of different preparation methods may provide single transition-metal oxides or compo- 
site oxide catalysts that can be used as substitutes for noble-metal catalysts, including Au and Ag, for VOC oxidation.

The catalytic activity in HCHO oxidation is affected by factors such as the preparation method, morphology and structure, specific surface area, active sites, low-temperature reducibility, and surface-active oxygen species; these factors are related to each other. Different preparation methods can provide various catalysts or supports with different morphologies or higher surface areas, which may further change some important factors such as the active sites, surface-active oxygen species, and low-temperature reducibility of the catalysts. Changing the methods used to prepare catalysts or supports is therefore an efficient way to obtain excellent catalytic activities in HCHO oxidation. Transition-metal oxides with special morphologies and their supported Ag or Au catalysts have promising low-temperature catalytic activities in HCHO oxidation because of the special preparation methods used. Catalytic HCHO conversion is also influenced by experimental parameters such as water vapor content, initial HCHO concentration, and GHSV. The activities of various HCHO oxidation catalysts were compared under the same condition. Changes in the GHSV and initial HCHO concentration are not useful in comparison of the oxidation activities of different catalysts. Normalized rates $(\mathrm{mol} /(\mathrm{m} \cdot \mathrm{h})$ or $\mathrm{mol} /(\mathrm{m} \cdot \mathrm{s}))$ and TOFs $\left(\mathrm{s}^{-1}\right.$ or $\left.\mathrm{h}^{-1}\right)$ should be used to express the activity in HCHO oxidation. In real situations, water vapor is often present in indoor environments and vehicle exhausts. It is therefore necessary to examine the effects of moisture on catalytic activity.

The development of effective and low-cost catalysts for HCHO oxidation at low temperatures, even room temperature, is still an important challenge. Catalyst preparation involves various factors such as choice of precipitant, deposition rate, hydrothermal time and temperature, $\mathrm{pH}$, templates, calcination temperature, auxiliaries, and choice of active components and supports. Much time has been spent on the preparation of catalytic materials, but catalysts with improved oxidation abilities are still needed. The experimental processes involved in synthesizing materials are difficult and complex. Compared with noble-metal catalysts, transition-metal oxides have better high-temperature catalytic activities, and it is very difficult to completely convert $\mathrm{HCHO}$ at room temperature. To control some of the factors influencing catalytic activity, such as struc- ture, morphology, and specific surface area, metal oxides with rod-like, spherical, and porous structures, with high surface areas, have been prepared using various synthetic methods to improve the catalytic performances in $\mathrm{HCHO}$ oxidation. For example, the low-temperature catalytic activities of 3D $\mathrm{Cr}_{2} \mathrm{O}_{3}$ and $3 \mathrm{D} \mathrm{Co}_{3} \mathrm{O}_{4}$, and $\mathrm{MnO}_{2}$ nanorods and nanospheres are better than those of traditional bulk $\mathrm{Cr}_{2} \mathrm{O}_{3}, \mathrm{Co}_{3} \mathrm{O}_{4}$, and $\mathrm{MnO}_{x}$. However, there is still a need for catalysts with special morphologies that can completely convert $\mathrm{HCHO}$ at low temperatures, even room temperature. Catalysts with carriers with different morphologies are promising for achieving complete $\mathrm{HCHO}$ conversion at low temperatures. A potential catalyst can be prepared by loading Pt or Pd on the support surface. However, a balance needs to be struck between the cost of precious metals and catalytic performance. Ag and $\mathrm{Au}$ are relatively cheap precious metals. The synthesis of catalysts consisting of Ag or Au loaded on metal oxide supports with special morphologies may be a future trend in developing catalysts supported on transition-metal oxides for complete conversion of $\mathrm{HCHO}$ at room temperature.

Research on the mechanism of HCHO oxidation is a sophisticated process; few mechanisms have been reported in the literature. To understand HCHO oxidation in depth, it is necessary to study the reaction mechanism further. The reaction mechanisms over more catalysts need to be reported in the future to obtain a more comprehensive understanding of HCHO oxidation. The structure-activity relationships of the catalysts also need to be further researched using various physical and chemical characterization techniques, especially in situ Raman, infrared, and near-edge X-ray absorption fine structure spectroscopies. The preparation and development of new nanocatalysts with various morphologies and structures will become a research trend in the future. Such materials can be used in the catalytic oxidation of HCHO and the catalytic oxidation of benzene series or other VOCs, and could provide techniques for decreasing VOC discharges from vehicle exhausts and industrial processes. The removal of VOCs helps to decrease of PM2.5 levels and to improve the atmospheric air quality.

\section{Acknowledgements}

This study was supported by the State Environmental Pro-

\section{Graphical Abstract}

Chin. J. Catal., 2016, 37: 102-122 doi: 10.1016/S1872-2067(15)61007-5

\section{Progress in research on catalysts for catalytic oxidation of formaldehyde}

Bingyang Bai*, Qi Qiao, Junhua Li*, Jiming Hao Chinese Research Academy of Environmental Sciences; Tsinghua University

This paper reviews progress in research on precious-metal and transition-metal oxide catalyst systems for HCHO oxidation. The oxidation properties, factors influencing the catalytic activity, and reaction mechanisms are discussed, and future development directions and research hotspots are considered.

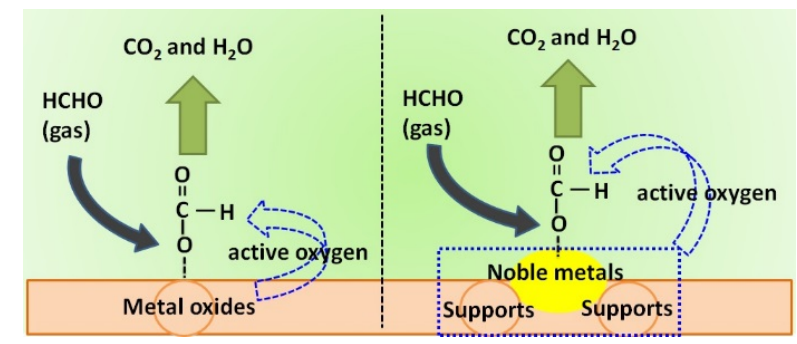


tection Key Laboratory of Sources and Control of Air Pollution Complex, and also supported by the State Key Laboratory of Environmental Criteria and Risk Assessment, Chinese Research Academy of Environmental Science.

\section{References}

[1] T. Salthammer, S. Mentese, R. Marutzky, Chem. Rev., 2010, 110, 2536.

[2] M. Hakim, Y. Y. Broza, O. Barash, N. Peled, M. Phillips, A. Amann, H. Haick, Chem. Rev., 2012, 112, 5949.

[3] O. S. Wenger, Chem. Rev., 2013, 113, 3686.

[4] R. J. Avery, Environ. Sci. Technol., 2006, 40, 4845.

[5] S. P. Chen, T. H. Liu, T. F. Chen, C. F. Ouyang, J. L. Wang, J. S. Chang, Environ. Sci. Technol., 2010, 44, 4635.

[6] C. Domeño, Á. Rodríguez-Lafuente, J. Martos, R. Bilbao, C. Nerín, Environ. Sci. Technol., 2010, 44, 2585.

[7] D. J. Luecken, M. R. Mebust, Environ. Sci. Technol., 2008, 42, 1615.

[8] B. Cardoso, A. S. Mestre, A. P. Carvalho, J. Pires, Ind. Eng. Chem. Res., 2008, 47, 5841.

[9] Y. C. Chiang, P. C. Chiang, C. P. Huang, Carbon, 2001, 39, 523.

[10] S. Brosillon, M. H. Manero, J. N. Foussard, Environ. Sci. Technol., 2001, 35, 3571.

[11] I. Ushiki, M. Ota, Y. Sato, H. Inomata, Fluid Phase Equilibr., 2015, 403, 78.

[12] N. Yao, K. L. Yeung, Chem. Eng. J., 2011, 167, 13.

[13] R. Tejasvi, M. Sharma, K. Upadhyay, Chem. Eng. J., 2015, 262, 875.

[14] M. Hussain, N. Russo, G. Saracco, Chem. Eng. J., 2011, 166, 138.

[15] F. Moulis, J. Krýsa, Catal. Today, 2013, 209, 153.

[16] F. Wang, H. X. Dai, J. G. Deng, G. M. Bai, K. M Ji, Y. X. Liu, Environ. Sci. Technol., 2012, 46, 4034.

[17] J. G. Deng, L. Zhang, H. X. Dai, Y. S. Xia, H. Y. Jiang, H. Zhang, H. He, J. Phys. Chem. C, 2010, 114, 2694.

[18] Q. Ye, J. S. Zhao, F. F. Huo, D. Wang, .S Y. Cheng, T. F. Kang, H. X. Dai, Microporous Mesoporous Mater., 2013, 172, 20.

[19] H. Arandiyan, H. X. Dai, J. G. Deng, Y. Wang, H. Y. Sun, S. H. Xie, B. Y. Bai, Y. X. Liu, K. M. Ji, J. H. Li, J. Phys. Chem. C, 2014, 118, 14913.

[20] H. Arandiyan, H. X. Dai, K. M. Ji, H. Y. Sun, J. H. Li, ACS Catal., 2015, 5, 1781.

[21] B. Y. Bai, J. H. Li, J. M. Hao, Appl. Catal. B, 2015, 164, 241.

[22] Y. Le, D. P. Guo, B. Cheng, J. G. Yu, Appl. Surf. Sci., 2013, 274, 110.

[23] Q. B. Wen, C. Q. Li, Z. H. Cai, W. Zhang, H. L. Gao, L. J. Chen, G. M. Zeng, X. Shu, Y. P. Zhao, Bioresource Technol., 2011, 102, 942.

[24] C. J. Ma, X. H. Li, T. L. Zhu, Carbon, 2011, 49, 2873.

[25] L. D. Zou, Y. G. Luo, M. Hooper, E. Hu, Chem. Eng. Process, 2006, 45, 959.

[26] J. Li, Z. Li, B. Liu, Q. B. Xia, H. X. Xi, Chin. J. Chem. Eng., 2008, 16, 871.

[27] D. Chen, Z. P. Qu, Y. H. Sun, Y. Wang, Colloid Surf. A, 2014, 441, 433.

[28] A. Rezaee, H. Rangkooy, A. Jonidi-Jafari, A. Khavanin, Appl. Surf. Sci, 2013, 286, 235.

[29] H. Q. Rong, Z. Y. Ryu, J. T. Zheng, Y. L. Zhang, Carbon, 2002, 40, 2291.

[30] K. J. Lee, N. Shiratori, G. H. Lee, J. Miyawaki, I. Mochida, S. H. Yoon, J. Jang, Carbon, 2010, 48, 4248.

[31] D. Chen, Z. P. Qu, W. W. Zhang, X. Y. Li, Q D Zhao, Y. Shi, Colloid Surf A, 2011, 379, 136.

[32] K. Kosuge, S. Kubo, N. Kikukawa, M. Takemori, Langmuir, 2007, 23, 3095.

[33] Y. W. Lu, D. H. Wang, C. F. Ma, H. C. Yang, Build. Environ., 2010, 45, 615.

[34] R. Akbarzadeh, S. B. Umbarkar, R. S. Sonawane, S. Takle, M. K.
Dongare, Appl. Catal. A, 2010, 374, 103.

[35] P. A. Bourgeois, E. Puzenat, L. Peruchon, F. Simonet, D. Chevalier, E. Deflin, C. Brochier, C. Guillard, Appl. Catal. B, 2012, 128, 171.

[36] P. F. Fu, P. Y. Zhang, J. Li, Appl. Catal. B, 2011, 105, 220.

[37] G. K. Zhang, Q. Xiong, W. Xu, S. Guo, Appl. Clay. Sci., 2014, 102, 231.

[38] Y. You, S. Y. Zhang, L. Wan, D. F. Xu, Appl. Surf. Sci., 2012, 258, 3469.

[39] X. B. Zhu, D. L. Chang, X. S. Li, Z. G. Sun, X. Q. Deng, A. M. Zhu, Chem. Eng. J., 2015, 279, 897.

[40] W. Low, V. Boonamnuayvitaya, J. Environ. Manage., 2013, 127, 142.

[41] M. Khanmohammadi, A. B. Garmarudi, H. Elmizadeh, M. B. Roochi, J. Ind. Eng. Chem., 2014, 20, 1841.

[42] B. Y. Bai, H. Arandiyan, J. H. Li, Appl. Catal. B, 2013, 142-143, 677.

[43] J. Quiroz Torres, S. Royer, J. P. Bellat, J. M. Giraudon, J. F. Lamonier, ChemSusChem, 2013, 6, 578.

[44] C. B. Zhang, H. He, K. I. Tanaka, Appl. Cataly. B, 2006, 65, 37.

[45] C. B. Zhang, H. He, Catal. Today, 2007, 126, 345.

[46] C. B. Zhang, F. D. Liu, Y. P. Zhai, H. Ariga, N. Yi, Y. C. Liu, K. Asakura, M. Flytzani-Stephanopoulos, H. He, Angew. Chem. Int. Ed., 2012, $51,9628$.

[47] L. H. Nie, J. G. Yu, X. Y. Li, B. Cheng, G. Liu, M. Jaroniec, Environ. Sci. Technol., 2013, 47, 2777.

[48] S. S. Kim, K. H. Park, S. C. Hong, Appl. Catal. A, 2011, 398, 96.

[49] N. H. An, W. L. Zhang, X. L. Yuan, B. Pan, G. Liu, M. J. Jia, W. F. Yan, W. X. Zhang, Chem. Eng. J., 2013, 215-216, 1.

[50] J. X. Peng, S. D. Wang, Appl. Catal. B, 2007, 73, 282.

[51] K. T. Chuang, B. Zhou, S. M. Tong, Ind. Eng. Chem. Res., 1994, 33, 1680.

[52] H. B. Huang, D. Y. C. Leung, J. Catal., 2011, 280, 60.

[53] H. B. Huang, D. Y. C. Leung, ACS Catal., 2011, 1, 348.

[54] S. J. Park, I. Bae, I. S. Nam, B. K. Cho, S. M. Jung, J. H. Lee, Chem. Eng. J., 2012, 195-196, 392.

[55] V. A. dela O'Shea, M. CÁlvarez-Galván, J. L. G. Fierro, P. L. Arias, Appl. Catal. B, 2005, 57, 191.

[56] Z. P. Qu, S. J. Shen, D. Chen, Y. Wang, J. Mol. Catal. A, 2012, 356, 171.

[57] C. F. Mao, M. A. Vannice, J. Catal., 1995, 154, 230.

[58] S. Imamura, D. Uchihori, K. Utani, T. Ito, Catal. Lett., 1994, 24, 377.

[59] K. Sekizawa, H. Widjaja, S. Maeda, Y. Ozawa, K. Eguchi, Appl. Catal. A, 2000, 200, 211.

[60] S. Minicò, S. Scirè, C. Crisafulli, R. Maggiore, S. Galvagno, Appl. Catal. B, 2000, 28, 245.

[61] S. Imamura, Y. Uematsu, K. Utani, T. Ito, Ind. Eng. Chem. Res., 1991, $30,18$.

[62] X. F. Tang, J. L. Chen, X. M. Huang, Y. D. Xu, W. J. Shen, Appl. Catal. B, 2008, 81, 115 .

[63] X. F. Tang, J. L. Chen, Y. G. Li, Y. Li, Y. D. Xu, W. J. Shen, Chem. Eng. J., 2006, 118, 119.

[64] Y. N. Shen, X. Z. Yang, Y. Z. Wang, Y. B. Zhang, H. Y. Zhu, L .Gao, M. L. Jia, Appl. Catal. B, 2008, 79, 142.

[65] H. F. Li, N. Zhang, P. Chen, M. F. Luo, J. Q. Lu, Appl. Catal. B, 2011, 110, 279.

[66] C. Y. Li, Y. N. Shen, M. L. Jia, S. S. Sheng, M. O. Adebajo, H. Y. Zhu, Catal. Commun., 2008, 9, 355.

[67] N. H. An, Q. S. Yu, G. Liu, S. P. Li, M. J. Jia, W. X. Zhang, J. Hazard. Mater., 2011, 186, 1392.

[68] H. Tian, J. H. He, L. L. Liu, D. H. Wang, Ceram. Int., 2013, 39, 315.

[69] X. H. Yu, J. H. He, D. H. Wang, Y. C. Hu, H. Tian, Z. C. He, J. Phys. Chem. C, 2011, 116, 851.

[70] Z. W. Huang, G. Xu, Q. Q. Cao, P. P. Hu, J. M. Hao, J. H. Li, X. F.Tang, Angew. Chem. Int. Ed., 2012, 51, 4198.

[71] P. P. Hu, Z. Amghouz, Z. W. Huang, F. Xu, Y. X. Chen, X. F. Tang, 
Environ. Sci. Technol., 2015, 49, 2384.

[72] J. Zhang, Y. Jin, C. Y. Li, Y. N. Shen, L. Han, Z. X. Hu, X. W. Di, Z. L. Liu, Appl. Catal. B, 2009, 91, 11.

[73] B. C. Liu, C. Y. Li, Y. F. Zhang, Y. Liu, W. T. Hu, Q. Wang, L. Han, J. Zhang, Appl. Catal. B, 2012, 111, 467.

[74] B. C. Liu, Y. Liu, C. Y. Li, W. T. Hu, P. Jing, Q. Wang, J. Zhang, Appl. Catal. B, 2012, 127, 47.

[75] C. Y. Ma, D. H. Wang, W. J. Xue, B. J. Dou, H. L. Wang, Z. P. Hao, Environ. Sci. Technol., 2011, 45, 3628.

[76] C. Y. Ma, Z. Mu, J. J. Li, Y. G. Jin, J. Cheng, G. Q. Lu, Z. P. Hao, S. Z. Qiao, J. Am. Chem. Soc., 2010, 132, 2608.

[77] Y. B. Zhang, Y. N. Shen, X. G. Yang, S. S. Sheng, T. Wang, M. F. Adebajo, H. Y. Zhu, J. Mol. Catal. A, 2010, 316, 100.

[78] B. Y. Bai, J. H. Li, ACS Catal., 2014, 4, 2753.

[79] L. Ma, D. S. Wang, J. H. Li, B. Y. Bai, L. X. Fu, Y. D. Li, Appl. Catal. B, 2014, 148-149, 36.

[80] R. H. Wang, J. H. Li, Catal. Lett., 2009, 131, 500.

[81] Y. Sekine, A. Nishimura, Atmos. Environ., 2001, 35, 2001.

[82] Y. Sekine, Atmos. Environ., 2002, 36, 5543.

[83] L. Zhou, J. Zhang, J. H. He, Y. C. Hu, H. Tian, Mater. Res. Bull., 2011, $46,1714$.

[84] T. Chen, H. Y. Dou, X. L. Li, X. F. Tang, J. H. Li, J. M. Hao, Microporous Mesoporous Mater., 2009, 122, 270.

[85] Y. Xu, J. Greeley, M. Mavrikakis, J. Am. Chem. Soc., 2005, 127, 12823.

[86] X. W. Xie, Y. Li, Z. Q. Liu, M. Haruta, W. J. Shen, Nature, 2009, 458, 746.

[87] D. Widmann, R. J. Behm, Angew. Chem. Int. Ed., 2011, 50, 10241.

[88] H. M. Chen, J. H. He, C. B. Zhang, H. He. J. Phys. Chem. C, 2007, 111, 18033.

[89] X. F. Tang, X. M. Huang, J. J. Shao, J. L. Liu, Y. G. Li, Y. D. Xu, W. J.
Shen, Chin. J. Catal., 2006, 27, 97.

[90] H. Tian, J. H. He, X. D. Zhang, L. Zhou, D. H. Wang, Microporous Mesoporous Mater., 2011, 138, 118.

[91] H. Tian, J. H. He, L. L. Liu, D. H. Wang, Z. P. Hao, C. Y. Ma, Microporous Mesoporous Mater., 2012, 151, 397.

[92] Y. S. Xia, H. X. Dai, L. Zhang, J. G. Deng, H. He, C. T. Au, Appl. Catal. $B, 2010,100,229$.

[93] B. Y. Bai, J. H. Li, J. M. Hao, Appl. Catal. B, 2015, 164, 241.

[94] B. Y. Bai, Q. Qiao, J. H. Li, J. M. Hao, Chin. J. Catal., 2015, 36, 27.

[95] X. F. Tang, Y. G. Li, X. M. Huang, Y. D. Xu, H. Q. Zhu, J. G. Wang, W. J. Shen. Appl. Catal. B, 2006, 62, 265.

[96] X. S. Liu, J. Q. Lu, K. Qian, W. X. Huang, M. F. Luo. J. Rare. Earth, 2009, 27, 418.

[97] Y. R. Wen, X. Tang, J. H. Li, J. M. Hao, L. S. Wei, X. F. Tang. Catal. Commun., 2009, 10, 1157.

[98] J. J. Pei, X. Han, Y. Lu, Build. Environ., 2015, 84, 134.

[99] L. Bai, F. Wyrwalski, J. F. Lamonier, A. Y. Khodakov, E. Monflier, A. Ponchel, Appl. Catal. B, 2013, 138-139, 381.

[100] Y. Wang, A. M. Zhu, B. B. Chen, M. Crocker, C. Shi, Catal. Commun., 2013, 36, 52.

[101] H. Arandiyan, H. X. Dai, J. G. Deng, Y. Wang, H. Y. Sun, S. H. Xie, B. Y. Bai, Y. X. Liu, K. M. Ji, J. H. Li, J. Phys. Chem. C, 2014, 118, 14913.

[102] H. Arandiyan, H. X. Dai, K. M. Ji, H. Y. Sun, J. H. Li, ACS Catal., 2015, 5, 1781.

[103] H. Over, A. P. Seitsonen, Science, 2002, 297, 2003.

[104] K. An, S. Alayoglu, N. Musselwhite, S. Plamthottam, G. Melaet, A. E. Lindeman, G. A. Somorjai, J. Am. Chem. Soc., 2013, 135, 16689.

[105] J. H. Li, R. H.Wang, J. M. Hao, J. Phys. Chem. C, 2010, 114, 10544.

[106] Y. X. Liu, H. X. Dai, J. G. Deng, S. H. Xie, H. G. Yang, W. Tan, W. Han, Y. Jiang, G. S. Guo, J. Catal., 2014, 309, 408.

\section{甲醛催化氧化催化剂的研究进展 \\ 拜冰阳 ${ }^{\mathrm{a}, \mathrm{b}, \#}$, 乔 琦, ${ }^{\mathrm{a}, \mathrm{b}}$, 李俊华 ${ }^{\mathrm{c},}{ }^{*}$, 郝吉明 ${ }^{\mathrm{c}}$ \\ ${ }^{\mathrm{a}}$ 中国环境科学研究院环境基准与风险评估国家重点实验室, 北京100012 \\ ${ }^{\mathrm{b}}$ 中国环境科学研究院国家环境保护生态工业重点实验室, 北京 100012 \\ $c^{c}$ 清华大学环境学院环境模拟与污染控制国家重点联合实验室, 北京 100084}

摘要: 甲醛是致癌致畸物并具有较强的光化学活性. 它既来源于纺织、农药、板材或其他精细化学品的生产过程, 又来源 于机动车尾气和室内各种装潢材料. 为了人体健康和大气环境去除甲醛非常必要. 用催化氧化法去除甲醛是一种很有前 景的技术, 但是该技术的关键是研究和发展催化剂. 近年来, 用于甲醛氧化的催化剂主要分为贵金属催化剂和过渡金属氧 化物催化剂.

贵金属催化剂是将Pt, Pd, Au, Ag等贵金属负载在不同类型的载体上而制得. 载体可分为常见载体、传统金属氧化物载 体和特殊形貌金属氧化物载体. 常见载体是具有较大比表面积的 $\mathrm{SiO}_{2}, \mathrm{Al}_{2} \mathrm{O}_{3}, \mathrm{TiO}_{2}$ 和分子篮等. 这类载体有利于活性位的 暴露以及反应物和产物的吸附和扩散, 而且还能增强载体和活性组分的协同作用. 负载在常见载体上的不同贵金属催化 剂, 其甲醛氧化活性从强到弱排列是: $\mathrm{Pt}>\mathrm{Pd}>\mathrm{Rh}>\mathrm{Au}>\mathrm{Ag}$. 用这种载体制备的催化剂具有很出色的应用前景. 比如 $\mathrm{Na}-\mathrm{Pt} / \mathrm{TiO}_{2}$ 是甲酫氧化活性最好的催化剂, 目前已被应用在空气净化器中, 其次是 $\mathrm{Pt} / \mathrm{TiO}_{2}$ 和 $\mathrm{Pd} / \mathrm{TiO}_{2}$. 传统金属氧化物载体 主要是采用沉淀法、共沉淀法制备的 $\mathrm{CeO}_{2}, \mathrm{Fe}_{2} \mathrm{O}_{3}, \mathrm{Co}_{3} \mathrm{O}_{4}, \mathrm{MnO}_{2}$ 及其复合氧化物, 这类载体负载Pt的催化剂仍然具有出色的 室温催化性能, 如 $\mathrm{Pt} / \mathrm{MnO}_{x}-\mathrm{CeO}_{2}$ 和 $\mathrm{Pt} / \mathrm{Fe}_{2} \mathrm{O}_{3}$ 等. 虽然 $\mathrm{Pt}$ 负载型催化剂应用前景很好, 但是其成本较高, 工业生产和普及受到 限制. 用传统金属氧化物载体制备的催化剂如 $\mathrm{Au} / \mathrm{CeO}_{2}, \mathrm{Ag} / \mathrm{MnO}_{x}-\mathrm{CeO}_{2}$ 和 $\mathrm{Ag} / \mathrm{CeO}_{2}$ 等同样具有良好的发展前景. 对于提高 甲醛氧化活性来说, 载体的选择至关重要. 未来研究趋势可能是甲醛氧化负载型催化剂更多的会选择Ag或Au作为活性组 分, 而一些有潜力的传统金属氧化物载体将被使用不同的制备方法进一步改良. 目前, 拥有棒状、球状、孔状等特殊形貌 的金属氧化物载体因为它们本身的催化活性要优于用沉淀法制备的传统金属氧化物催化剂, 因此, 将 $\mathrm{Ag}$ 或 $\mathrm{Au}$ 负载在这类 载体上制备的催化剂具有更好的应用前景, 如三维(3D)有序大孔 $\mathrm{Au} / \mathrm{CeO}_{2}-\mathrm{Co}_{3} \mathrm{O}_{4}$, 二维有序介孔 $\mathrm{Au} / \mathrm{Co}_{3} \mathrm{O}_{4}-\mathrm{CeO}_{2}$ 和 $\mathrm{Au} / \mathrm{Co}_{3} \mathrm{O}_{4}$ 
以及三维有序介孔 $\mathrm{K}-\mathrm{Ag} / \mathrm{Co}_{3} \mathrm{O}_{4}$ 等.

过渡金属氧化物催化剂, 因成本低, 资源丰富而受到关注. 单一过渡金属氧化物催化剂如锰钾矿型的 $\mathrm{MnO}_{2}$ 纳米棒或纳 米球, 介孔 $\mathrm{MnO}_{2}, \mathrm{Co}_{3} \mathrm{O}_{4}$ 和 $\mathrm{Cr}_{2} \mathrm{O}_{3}$ 等, 具有较好的甲醛氧化催化活性 $\left(T_{50}\right.$ 和 $T_{100}$ 分别小于等于 110 和 $\left.140{ }^{\circ} \mathrm{C}\right)$. 另外, $\mathrm{Ce}, \mathrm{Sn}, \mathrm{Cu}$ 和 $\mathrm{Zr}$ 等元素常常被掺杂到 $\mathrm{MnO}_{x}$ 和 $\mathrm{Co}_{3} \mathrm{O}_{4}$ 中, 制备成复合金属氧化物催化剂, $\mathrm{MnO}_{x}-\mathrm{CeO}_{2}$ 具有较好的甲醛催化活性 $\left(T_{50}<\right.$ $\left.100{ }^{\circ} \mathrm{C}\right)$, 因为 $\mathrm{MnO}_{x}$ 和 $\mathrm{CeO}_{2}$ 较强的相互作用改变了表面活性氧和活性相的数量. 目前, 复合金属氧化物催化剂氧化甲酫的 报道很少. 随着制备方法的改变, 单一过渡金属氧化物或他们的复合氧化物催化剂可能会成为贵金属催化剂的替代品.

目前, 如何获得高效、低成本、低温甚至常温去除甲醛的催化剂仍然是一项重要的挑战. 特殊形貌的金属氧化物催化 剂如3D- $\mathrm{Cr}_{2} \mathrm{O}_{3}, 3 \mathrm{D}-\mathrm{Co}_{3} \mathrm{O}_{4}, \mathrm{MnO}_{2}$ 纳米球和纳米棒, 在常温下完全转化甲醛仍然是个难以越过的鸿沟.

将来, 多种形貌的新型纳米金属氧化物及其Au或Ag负载型催化剂的制备和发展会成为一个研究趋势. 这种催化剂既 能被用于甲醛的催化氧化, 也能被用于苯系物或其他VOCs的催化氧化. 它能为机动车尾气和工业生产中VOCs产生量的 削减提供技术支撑, 而VOCs的去除有益于PM2.5浓度的降低和空气质量的恢复.

关键词: 甲醛; 催化氧化; 金属氧化物催化剂; 贵金属催化剂; 低温催化活性

收稿日期: 2015-08-27. 接受日期: 2015-10-20. 出版日期: 2016-01-05.

*通讯联系人. 电话/传真: (010)62771093; 电子信箱: lijunhua@tsinghua.edu.cn

\#通讯联系人. 电话: (010)84914902; 传真: (010)84914626; 电子信箱: baibingyang@tsinghua.org.cn

基金来源: 国家自然科学基金(21325731, 51478241, 21221004).

本文的英文电子版由Elsevier出版社在ScienceDirect上出版(http://www.sciencedirect.com/science/journal/18722067). 